\title{
BOOM-BUSTS IN ASSET PRICES, ECONOMIC INSTABILITY, AND MONETARY POLICY
}

\author{
Michael D. Bordo \\ Olivier Jeanne
}

Working Paper 8966

http://www.nber.org/papers/w8966

\author{
NATIONAL BUREAU OF ECONOMIC RESEARCH \\ 1050 Massachusetts Avenue \\ Cambridge, MA 02138 \\ June 2002
}

Previous versions of this paper benefited from comments by Ben Bernanke, Luis Catao, Mark Gertler, Charles Goodhart, Allan Meltzer, and Anna Schwartz. The views expressed herein are those of the authors and not necessarily those of the National Bureau of Economic Research or the IMF.

(C) 2002 by Michael D. Bordo and Olivier Jeanne. All rights reserved. Short sections of text, not to exceed two paragraphs, may be quoted without explicit permission provided that full credit, including $\odot$ notice, is given to the source. 
Boom-Busts in Asset Prices, Economic Instability, and Monetary Policy

Michael D. Bordo and Olivier Jeanne

NBER Working Paper No. 8966

June 2002

JEL No. E52, N20

\begin{abstract}
The link between monetary policy and asset price movements has been of perennial interest to policy makers. In this paper we consider the potential case for pre-emptive monetary restrictions when asset price reversals can have serious effects on real output. First, we provide some historical background on two famous asset price reversals: the U.S. stock market crash of 1929 and the bursting of the Japanese bubble in 1989. We then present some stylized facts on boom-bust dynamics in stock and property prices in developed economies. We then discuss the case for a pre-emptive monetary policy in the context of a stylized "Dynamic New Keynesian" framework with collateral constraints in the productive sector. We find that whether such a policy is warranted depends on the economic conditions in a complex, non-linear way. The optimal policy cannot be summarized by a simple policy rule of the type considered in the inflation-targeting literature.
\end{abstract}

Michael D. Bordo

Department of Economics

Rutgers University

New Jersey Hall

New Brunswick, NJ 08901

and NBER

bordo@econ.rutgers.edu
Olivier Jeanne

Research Department

International Monetary Fund

700 19th Street

Washington, DC 20431

ojeanne@imf.org 


\title{
$\underline{\text { Boom - Busts in Asset Prices, Economic Instability, and Monetary Policy }}{ }^{1}$
}

\author{
Michael Bordo and Olivier Jeanne
}

April 2002

\section{$\underline{\text { 1. Introduction }}$}

The link between monetary policy and asset price movements has been of perennial interest to policy makers. The 1920s stock market boom and 1929 crash and the 1980s Japanese asset bubble are two salient examples where asset price reversals were followed by protracted recessions and deflation. ${ }^{2}$ The key questions that arise from these episodes is whether the monetary authorities could have been more successful in preventing the consequences of an asset market bust or whether it was appropriate for the authorities only to react to these events ex post.

In this paper we consider the potential cases for proactive versus reactive monetary policy based on the situation where asset price reversals can have serious effects on real output. Our analysis is based on a stylized model of the dilemma with which the monetary authorities are faced in asset price booms. On the one hand, letting the boom go unchecked entails the risk that it will be followed by a bust, accompanied by a collateral induced credit crunch. Restricting monetary policy can be thought of as an insurance against the risk of a credit crunch. On the other hand, this insurance does not come free: restricting monetary policy implies immediate costs in terms of lower output and inflation. The optimal monetary policy depends on the relative cost and benefits of the insurance. ${ }^{3}$

Although the model is quite stylized, we find that the optimal monetary policy depends on the economic conditions - including the private sector's beliefs - in a rather complex way. Broadly speaking, a proactive monetary restriction is the optimal policy when the risk of a bust is large and the monetary authorities can defuse it at a relatively low cost. One source of difficulty is that in general, there is a tension between these two conditions. As investors become more exuberant, the risks associated with a reversal in market sentiment increase. At the same time, leaning against the wind of investors' optimism requires more radical and costly monetary actions. To be optimal, a proactive monetary policy must come into play at a time

\footnotetext{
${ }^{1}$ For valuable research assistance we thank Priya Joshi.

${ }^{2}$ Other recent episodes of asset price booms and collapses include experiences in the 1980s and 1990s in the Nordic Countries, Spain, Latin America and East Asia, see e.g. Schinasi and Hargreaves (1993); Drees and Pazarbasioglu (1998); IMF World Economic Outlook (2000); and Collyns and Senhadji (2002).

${ }^{3}$ It is important to note that we do not address the case where asset price movements act as predictors of future inflation. The evidence on this issue is mixed (see Filardo 2000).
} 
when the risk is perceived as sufficiently large but the authorities' ability to act is not too diminished.

Another, more difficult question is whether (and when) the conditions for a proactive monetary policy are met in the real world. We view this question as very much open and deserving further empirical research. In the meantime, we present in this paper some stylized facts on asset booms and busts that have some bearing on the issue. We find that historically, there have been many booms and busts in asset prices, but that they have different features depending on the countries and whether one looks at stock or property prices. Boom-bust episodes seem to be more frequent in real property prices than in stock prices, and in small countries than in large countries. However, two dramatic episodes (the US in the Great Depression and Japan in the 1990s) have involved large countries and the stock market. We also present evidence that busts are associated with disruption in financial and real activity (banking crises, slowdown in output and decreasing inflation).

This paper is related to growing policy and academic literatures on monetary policy and asset prices. On the policy side, the dominant view among central bankers is that in response to movements in asset prices, monetary policy should be reactive, not proactive, e.g.

"[...] the general view nowadays is that central banks should not try to use interest rate policy to control asset price trends by seeking to burst any bubbles that may form. The normal strategy is rather to seek, firmly and with the help of a great variety of instruments, to restore stability on the few occasions when asset markets collapse."

(Ms Hessius, Deputy Governor of the Sveriges Risksbank, BIS Review 128/1999).

This view is vindicated, on the academic side, by the recent work of Bernanke and Gertler (2000). These authors argue that a central bank dedicated to price stability should pay no attention to asset prices per se, except insofar as they signal changes in expected inflation. These results stem from the simulation of different variants of the Taylor rule in the context of a new keynesian model with sticky wages and a financial accelerator. Bernanke and Gertler also argue that trying to stabilize asset prices per se is problematic because it is nearly impossible to know for sure whether a given change in asset values results from fundamental factors, non-fundamental factors, or both.

In another study, Cecchetti et al (2000) have argued in favor of a more proactive response of monetary policy to asset prices. They agree with Bernanke and Gertler that the monetary authorities would have to make an assessment of the bubble component in asset prices, but take a more optimistic view of the feasibility of this task. ${ }^{4}$ They also argue, on the basis of simulations of the Bernanke-Gertler model, that including an asset price variable (e.g. stock prices) in the Taylor rule would be desirable. Bernanke and Gertler (2001) attribute the latter findings to the use of a misleading metric in the comparison between policy rules.

${ }^{4}$ Assessing the bubble component in asset prices should not be qualitatively more difficult, they argue, than measuring the output gap, an unobservable variable which many central banks use as an input into policymaking. 
Our approach differs from these in several respects. First, we view the emphasis on bubbles in this debate as excessive. In our model the monetary authority needs to ascertain the risk of an asset price reversal but it is not essential whether the reversal reflects a bursting bubble or fundamentals. Non-fundamental influences may exacerbate the volatility of asset prices and thus complicate the monetary authorities' task, but they are not of the essence of the question. Even if asset markets were completely efficient, abrupt price reversals could occur, and pose the same problem for monetary authorities as bursting bubbles.

Second, we find that the optimal policy rule is unlikely to take the form of a Taylor rule, even if it is augmented by a linear term in asset prices. If there is scope for proactive monetary policy, it is highly contingent on a number of factors for which output, inflation and the current level of asset prices do not provide appropriate summary statistics. It depends on the risks in the balance sheets of private agents assessed by reference to the risks in asset markets. The balance of these risks cannot be summarized in two or three macroeconomic variables, and it is shifting over time.

More generally, our analysis points to the risks of using simple monetary policy rules as the guide for monetary policy. These rules are blind to the fact that financial instability is endogenous - to some extent, and in a complex way - to monetary policy. The linkages between asset prices, financial instability and monetary policy are complex because they are inherently non-linear, and involve extreme (tail probability) events. The complexity of these linkages does not imply, however, that they can be safely ignored. Whether they like it or not, the monetary authorities need to take a stance that involves some judgment over the probability of extreme events. As our model illustrates, the optimal stance cannot be characterized by a simple rule. If anything, our analysis emphasizes the need for some discretionary judgment in monetary policy.

The paper is structured as follows. As background to the analysis, Section 2 reviews some of the salient features of two famous episodes of asset price reversals associated with extreme economic distress: the Interwar Great Depression experience of the U.S. and the Japanese asset price boom and bust in the 1980s and 1990s. In section 3 we present stylized facts on boom and bust cycles in asset prices in the post 1970 experience of 15 OECD countries. Section 4 presents the model and discusses policy implications. Section 5 concludes.

\section{Section 2. Historical Perspectives: Two dramatic episodes}

Asset price reversals have been an important phenomenon since the dawn of capitalism. Classic examples of a boom-bust cycle were the tulip mania in the early seventeenth century (Garber 2000) and the South Sea bubble in England in the early eighteenth century (Kindleberger 1989). In this section, as historical background to our analysis, we document the two most dramatic episodes of asset price reversals of the twentieth century: the 1929 U.S. stock market crash and the Japanese "asset price bubble" of the late 1980s and early 1990's. In both of these episodes asset price reversals played a major role in precipitating severe recessions. 


\subsection{The U.S. 1929-1933}

The Great Contraction in the U.S 1929-1933 is often associated with a classic boom and bust episode in the stock market (see figure 1). The boom, focussed on the 'new economy' stocks such as GE and RCA, according to legend began in 1926, turned into a bubble in March 1928 which burst on October 24, 1929 (Galbraith 1958, Kindleberger 1987). The bottom was not reached until 1932. The boom, which some argue was fueled by expansionary Federal Reserve policy in the spring of 1927, was financed by easy bank credit (see figure 3) and brokers loans (White 1990). The bust, it is sometimes argued was triggered by tight Federal Reserve policy in 1929 to prick what they perceived as a stock market bubble (Friedman and Schwartz 1963).

Beginning in late 1927 the Federal Reserve Board favored a policy of moral suasion to discourage member banks from financing stock market speculation, an activity viewed as anathema to the prevailing 'real bills' doctrine. This policy was opposed by Benjamin Strong, President of the New York Fed and head of the influential Open Market Investment Committee and after he became seriously ill and died in October 1928, by his successor George Harrison. They advocated a rise in the discount rate as the method to stem speculation. The stalemate, which it is argued allowed the stock market boom to continue unchecked, lasted until August 1929, the cyclical peak, when the discount rate was raised from 5 to 6 percent (Meltzer 2002).

The ensuing stock market crash in October 1929 in which stock prices declined by 40 percent in two months (see Figure 1) is not generally viewed as the key cause of the severity of the contraction that followed but as having some impact on household wealth, expenditures on consumer durables and expectations (Romer 1992). The source of the subsequent depression in 1930-33 was a series of banking panics, which led to a collapse in money supply, financial intermediation and aggregate demand (Friedman and Schwartz 1963, Bernanke 1983).

Asset price deflation however was an important ingredient in the propagation of the Great Contraction (Bernanke and Gertler 1989) because declining asset prices (both stock prices and land prices, see Figures 1 and 2) reduced the value of bank loans and collateral (see Figure 3); weakened banks in turn dumped their loans and securities in fire sales leading to further asset price deflation. In this environment of massive bank failures, greatly reduced collateral, and negligible bank lending, financial intermediation seized up, significantly exacerbating the distress of the real economy. Especially hard hit by the plunge in asset prices were savings and loan associations whose assets were pummeled by the decline in real estate prices and delinquent mortgage payments. Life insurance companies were also hard hit. If their mortgages and bonds had been marked to market, most companies would have been insolvent (White 2000). ${ }^{5}$

${ }^{5}$ Deflation was also an important ingredient in the Great Depression. Its role is well described by Irving Fisher's debt deflation story (Fisher 1933) in which collapsing prices led to a rise in debt burdens in an environment where contracts were not fully indexed. Deflation reduced the value of firms' net worth and the collateral for bank loans. This produced widespread 
The recovery began on March 1933 after the Banking Holiday and massive reflation following the devaluation of the dollar and Treasury gold and silver purchase programs (Romer 1990). The real economy however took close to a decade to recover to its predepression level of activity and may have taken longer in the absence of World War II. Asset prices took two decades to recover as did the value of collateral and private financial intermediation.

\section{$\underline{\text { 2.2 Japan 1986-1995 }}$}

The Japanese boom- bust cycle began in the mid 1980's with a run-up of real estate prices (see figure 4) fueled by an increase in bank lending (figure 6) and easy monetary policy. The property price boom in turn led to a stock market boom (figure 5) as the increased value of property owned by firms raised future profits and hence stock prices (Iwaisako and Ito 1995). Both rising land prices and stock prices in turn increased firms' collateral encouraging further bank loans and more fuel for the boom. The bust may have been triggered, like the U.S. example 60 years earlier, by the Bank of Japan's pursuit of a tight monetary policy in 1989 to stem the asset market boom.

The subsequent asset price collapse in the next 5 years led to a collapse in bank lending with a decline in the collateral backing corporate loans (see figure 6). The decline in asset prices further impinged on the banking system's capital making many banks insolvent. This occurred largely because the collapse in asset prices reduced the value of their capital (in Japan commercial banks could hold their capital in the form of stock market equity, see Kanaya and Woo 2000, Bayoumi and Collyns 2000).

Lender of last resort policy prevented a classic banking panic as had occurred in the U.S. in the 1930's but regulatory forbearance has propped up insolvent banks. The banking crisis has yet to be resolved, bank lending remains moribund, and Japan 13 years after the bust is still mired in stagnation and deflation in the face of tight monetary policy and the slow resolution of bank in solvencies. Thus in the Japanese case because of tight connections between asset prices, collateral, bank lending and banking capital, the boom bust episode has been crucially intertwined with serious macroeconomic instability.

insolvency for both firms and banks. Declining real activity also reduced collateral by weakening the performance of assets. 


\section{Section 3. Identifying booms and busts in asset prices: The Post-war OECD}

Many countries have experienced asset price booms and busts since 1973. Although none were as dramatic as the U.S. and Japan cases, a number were followed by serious recessions. In this section we develop a methodology to delineate boom and bust cycles in asset prices. We apply this methodology to real annual stock and residential property price indexes for 15 countries: Australia, Canada, Denmark, Finland, France, Germany, Ireland, Italy, Japan, the Netherlands, Norway, Spain, Sweden, the U.K. and the U.S. over the period 1970-2001 for stocks and 1970-98 for property prices. ${ }^{6}$

\subsection{Methodology}

This section presents a criterion to ascertain whether movements in an asset price represents a boom or bust. A good criterion should be simple, objective and yield plausible results. In particular, it should select the notorious boom-bust episodes, such as the Great Depression in the U.S. or Japan 1986-1995, without producing (too many) spurious episodes. We found that the following criterion broadly satisfied these conditions - although it certainly is not the only one.

Our criterion compares a moving average of the growth rate in asset prices with the long-run historical average. Let $g_{i, t}=\log \left(P_{i, t} / P_{i, t-1}\right)-1$ be the growth rate in the real price of the asset (stock prices or property prices) in year $t$ and in country $i$. Let $\bar{g}$ be the average growth rate over all countries. Let $v$ be the volatility (standard deviation) in the growth rate $g$, also measured by aggregating all of the countries together.

Then if the average growth rate between year $t-3$ and year $t$ is larger than a threshold:

$$
\frac{g_{i, t}+g_{i, t-1}+g_{i, t-2}}{3}>\bar{g}+x v
$$

we identify a boom in years $t-2, t-1$ and $t$.

Conversely we identify a bust in years $t-2, t-1$ and $t$ if

$$
\frac{g_{i, t}+g_{i, t-1}+g_{i, t-2}}{3}<\bar{g}-x v
$$

Our method detects a boom or a bust when the three-year moving average of the growth rate in the asset price falls outside a confidence interval defined by reference to the historical first and second moments of the series. Variable $x$ is a parameter that we calibrate so as to select the notorious boom-bust episodes without selecting (too many) spurious events. (We implement some sensitivity analysis with respect to this parameter.) We use the three-year

\footnotetext{
${ }^{6}$ Some data points are missing for some countries. The source for the stock price data is IFS, for property prices is BIS.
} 
moving average so as to eliminate the high frequency variations in the series. (This is particularly a problem with stock prices, which are more volatile than property prices.)

For real property prices the average growth rate across the 15 countries is 1.1 percent with an average volatility of 5.8 percent. For real stock prices the growth rate and the volatility are both higher, 2.9 percent and 13.6 percent respectively. For both prices we take $x=1.3$. $^{7}$

\subsection{Boom - Busts in the OECD 1970-2001}

Figures 7 and 8 show the $\log$ of the real prices of stocks and property ${ }^{8}$, with the boom and bust periods marked with shaded and clear bars respectively. We define a boombust episode as a boom followed by a bust that starts no later than one-year after the end of the bust. For example, Sweden (1987-1994) exhibits a boom-bust in real property prices but Ireland (1977-1984) does not, because the boom and the bust are separated by a two-years interval (see Figure 7).We also show banking crises marked by an asterisk country by country. ${ }^{9}$ A few facts stand out.

First, boom-bust episodes are much more prevalent in property prices than in stock prices. Out of 24 boom episodes in stock prices only three are followed by busts: Finland (1988), Japan (1989), Spain (1988) ${ }^{10}$. (We give the last year of the boom in parentheses.) Hence the sample probability of a boom ending up in a bust is 12.5 percent. Of course Japan is a very significant boom-bust episode. Also there might be more boom-bust episodes in the making since it is too early to tell whether the recent slides in stock markets in all countries are busts. ${ }^{11}$

Out of 19 booms in property prices, 10 were followed by busts: Denmark (1986), Finland (1989), Italy (1981), Japan (1973, 1990), the Netherlands (1977), Norway (1987), Sweden (1989),

\footnotetext{
${ }^{7}$ We experimented with different values of $x$ and the number of boom-bust episodes decline as $\mathrm{x}$ increases. Thus for property prices at $\mathrm{x}=1.0$, there are 16 boom-bust and for stock prices there are 5 . We settled on $x=1.3$ because lowering the threshold below that level produces an excessively large number of booms and busts.

${ }^{8}$ The logs were normalized to show only positive values.

${ }^{9}$ The data on banking crises come from Eichengreen and Bordo (2002).

${ }^{10}$ If we were to take a lower threshold such as $\mathrm{x}=1.0$, then, two more countries would be listed as having boom-busts: Italy and Sweden.

${ }^{11}$ Note that the incidence of a boom-bust episode by our criterion is very different from what is usually referred to as a stock market crash. For the U.S. for example, Mishkin and White (2002) document 15 crashes 1900-2000 and 4 from 1970-2000. They define a crash as a 20 percent decline in stock prices in a 12-month window.
} 
and the United Kingdom $(1973,1989) .{ }^{12}$ The probability of a boom in property prices ending up in a bust is 52.5 percent. That is, more than one in two property booms end up in a bust, against one in eight for stock market booms. Only two countries had boom-busts in both stock prices and property prices, Japan and Finland. In both cases the peaks virtually coincided.

One explanation for the larger number of boom-bust episodes in property prices than in stock prices may be that property price episodes are often local phenomenon occurring in the capital or major cities of a country. This would explain their high incidence in small countries like Finland or even in countries with relatively large populations like the U.K., where the episode occurred in London and environs. The fact that no such episodes are found in the U.S. may reflect the fact that boom-busts in property prices that occurred in New York, California and New England in the 1990's washed out in a national average index.

Second, in a number of cases, banking crises occurred either at the peak of the boom or after the bust. This is most prominent in the cases of Japan and the Nordic countries.

Finally, to provide historical perspective to our methodology, we do the same calculations for two U.S. stock price indexes for the last century: the S and P 500 from 1874 to 1999 and the Dow Jones Industrial Average from 1900 - 1999. As can be seen in figures 9 and 10, there are very few boom-bust episodes. The crash of 1929 stands out in both figures. In the $\mathrm{S}$ and $\mathrm{P}$ we also identify a boom bust in 1884, the year of a famous Wall Street crash associated with speculation in railroad stocks and political corruption, and one in 1937, the start of the third most serious recession of the twentieth century. ${ }^{13}$ As is well known the bust of 1929 is followed by banking crises in each of the years from 1930-1933.

\section{$\underline{\text { 3.3 Ancillary Variables }}$}

Associated with the boom bust episodes for property and stock prices that we have isolated above, we display figures for three macro variables directly related to the asset price reversals: CPI inflation, the real output gap and domestic private credit. ${ }^{14}$ The figures are averages of each variable across all the boom-bust episodes demarcated above. The 7-year time window shown is centered on the last year of the boom.

In figure 11 for property price boom- busts we observe inflation (panel A) rising until the year after the boom ends and then falling with the bust, while the output gap plateaus the year before the boom ends and then declines with the bust (panel B). Domestic private credit (panel C)

\footnotetext{
12 Again, a lower threshold of $x=1.0$ would add in Ireland and Spain.

${ }^{13}$ Using a lower threshold of $\mathrm{x}=1.0$ does not change the outcome.

14 Private Credit, line 22d of IFS is defined as "claims on the private sector of Deposit Money Banks (which comprise commercial banks and other financial institutions that accept transferable deposits, such as demand deposits)."
} 
continues to rise until the year after the boom peaks and then plateaus. ${ }^{15}$ This pattern is remarkably consistent with the scenario relating asset price reversals to the incidence of collateral, to the credit available to liquidity constrained firms and to economic activity that we develop in section 4 below.

Figure 12 shows the behavior of inflation, the output gap and domestic private credit averaged across the three boom-bust episodes in stock prices demarcated in figure 8. Inflation rises to a peak with the end of the boom and then declines, although not as precipitously as with the property price episodes (panel A). The output gap plateaus the year the boom ends and then declines in the bust (panel B). Domestic credit slows down its rate of increase the year after the boom ends and then declines (panel C). Although the pattern displayed for the 3 ancillary variables for stock price boom-busts is quite similar to that seen in figure 11, we attach more weight to the property price pattern because it is based on a much larger number of episodes (12 versus 3 ).

With this descriptive evidence as background, in section 4 below we develop a model to help us understand the relationship between boom-busts, the real economy and monetary policy.

\section{Section 4. Theory}

A regular feature of boom-bust episodes is that the fall in asset prices is associated with a slowdown in economic activity (sometimes negative growth), as well as financial and banking problems. There may be a number of explanations for this pattern, and they do not all give a central role to asset prices. ${ }^{16}$ However, there is evidence that the bust in asset prices contributes to the fall in output by generating a credit crunch. The domestic private sector accumulates a high level of debt in the boom period; when asset prices fall, the collateral base shrinks, and so do firms' ability to finance their operations. ${ }^{17}$

This section addresses the following question. Assuming that asset market booms involve the risk of a reversal in which the economy falls prey to a collateral-induced credit crunch, what is the consequence of this risk for the design of monetary policy?

There are two ways in which monetary policy can respond. First, there is the reactive approach. The monetary authorities wait and see whether the asset collapse occurs, and if it does, respond accordingly. This is consistent with standard monetary policy rules, such as the Taylor rule,

15 The figure shows the nominal level of private domestic credit. Real private domestic credit declines in the year after the boom peaks.

${ }^{16}$ For example, bad news about future productivity could cause financial and banking problems at the same time as a slowdown in economic activity, without causality from the former to the latter.

17 This meaning of a collateral-induced credit crunch differs from an earlier meaning which viewed a credit crunch as a restriction on bank lending induced by tightening monetary policy. 
which imply an accommodating response ex post. If need be, this monetary relaxation can be complemented by a lending-in-last-resort injection of liquidity in order to stabilize the financial system (Bernanke and Gertler 2000).

Second, there is a more pro-active approach to dealing with asset price developments. The monetary authorities might attempt to contain the rise in asset prices and domestic credit in the boom phase in the hope of mitigating the consequences of a bust, if it occurs. This may be consistent with standard monetary policy rules, which also imply a monetary restriction if the boom is associated with inflation pressures and overheating of the economy. However, the monetary authorities may want to restrict monetary policy above and beyond what standard rules prescribe. The question, then, is in which circumstances the authorities should deviate from standard rules, and on which indicators should they base monetary policy in these cases.

This section presents a stylized model that clarifies the difference between the two views, and draws some implications for monetary policy. Unlike a number of related papers (Bernanke and Gertler, 2000; Batini and Nelson, 2000; Cecchetti et al, 2000), the aim is not to compare the performance of different monetary policy rules in the context of a realistic, calibrated model of the economy. Rather, it is to highlight the difference between a proactive monetary policy and a reactive monetary policy in the context of a simple and transparent framework. It turns out that although the model is quite simple, the optimal monetary policy is not trivial, and depends on the exogenous economic conditions in a non-linear way. Although this nonlinearity complicates the analysis, we think it is an essential feature of the question we study in this paper because financial crises are inherently non-linear events. We hope that in a second step, the approach can be transposed to more realistic models of the economy.

Our analysis is based on a reduced-form model that is very close to the standard undergraduate text-book macroeconomic model. In the appendix we provide micro-foundations in the spirit of the "Dynamic New Keynesian" literature. Private agents have utility functions and optimize intertemporally. The government prints and distributes money, which is used because of a cash-in-advance constraint. Nominal wages are predetermined, giving rise to a short-run Phillips Curve. Monetary policy has a credit channel, based on collateral. The collateral is productive capital; its price is driven by the expected level of productivity in the long run.

The reduced-form model has two periods $t=0,1$. Period 0 is the period in which the problem "builds up" (debt is accumulated). In period 1, the long-run level of productivity is revealed. An asset market crash may or not occur, depending on the nature of the news. If the long-run level of productivity is lower than expected, the price of the asset falls, reducing the collateral basis for new borrowing. If the price of collateral is excessively low relative to firms' debt burden, the asset market crash provokes a credit crunch and a fall in real activity.

Note that these market dynamics are completely driven by the arrival of news on long-run productivity. The asset market boom is not caused by a monetary expansion or a bubble. Nor is the crash caused by a monetary restriction, or a self-fulfilling liquidity crisis. Irrational expectations or multiple equilibria can be introduced into the model, but keeping in line with our desire to stay close to the textbook framework, we prefer to abstract from these considerations in the benchmark model. At the end of this section we briefly discuss a variant 
of the model in which investors are "irrationally exuberant". The appendix presents a variant of the model in which investors are rational but asset market crashes are self-fulfilling.

\subsection{The model}

The equations of the reduced-form model are as follows.

$$
\left\{\begin{array}{l}
y_{t}=m_{t}-p_{t} \\
y_{t}=\alpha p_{t}+\varepsilon_{t}(2) \\
y_{0}=-\sigma r
\end{array}\right.
$$

where $y_{t}$ is output at time $t, m_{t}$ is money supply, $p_{t}$ is the price level and $r$ is the real interest rate between period 0 and period 1 . All variables, except the real interest rate, are in logs.

The first two equations characterizes aggregate demand and aggregate supply. Aggregate supply is increasing with the nominal price level because the nominal wage is sticky. The third equation says that the first-period output is decreasing with the real interest rate. It is based, in the micro-founded model, on the Euler equation for consumption.

The key difference between our model and the standard macro model is the "supply shock", $\varepsilon$. In the standard model the supply shock is an exogenous technological shock or more generally, any exogenous event which affects the productivity of firms (e.g., an earthquake). Here the supply shock is instead a "financial" shock and it is not entirely exogenous, since its distribution depends on firms' debt and the price of assets, two variables that monetary policy may influence. That monetary policy can influence debt accumulation ex ante (in period 0 ) plays a central role in our analysis of proactive monetary policy.

The supply shock $\varepsilon$ results from the occurrence of a credit crunch in the corporate sector. For simplicity, we assume that the credit crunch can occur only in period 1:

$\varepsilon_{0}=0$

$\left\{\begin{array}{cl}\varepsilon_{1}=0 & \text { if no credit crunch } \\ =-v & \text { if } \text { credit crunch. }\end{array}\right.$

In the micro-founded model, the occurrence of a credit crunch depends on two variables: the debt burden of the corporate sector and the price of collateral. Firms issue a quantity of debt $D$ in period 0 and must repay $(1+r) D$ in period 1 . (Debt is in real terms.) In addition, some firms must obtain new credit in period 1 to finance working capital. The firms that need but do not obtain this intra-period credit simply do not produce, which reduces aggregate supply. 
In period 1, the firms' access to new credit depends on the value of their collateral. Because of a debt renegotiation problem a la Hart and Moore (1994), firms' total debt cannot exceed the value of their collateral. Denoting by $Q_{1}$ the real value of collateral in period 1 , and by $\gamma$ the required level of intra-period credit, the firms that require intra-period credit can operate if and only if $(1+r) D+\gamma \leq Q_{1}$. There is a credit crunch if and only if this condition is not satisfied.

$$
Q_{1}<(1+r) D+\gamma
$$

That is, there is a credit crunch if the value of firms'collateral is low relative to their debt burden.

\section{$\underline{4.2}$ Monetary policy and financial fragility}

Monetary policy influences the two key variables that determine the occurrence of a credit crunch in period 1. First, a monetary expansion ex post (in period 1) should increase the price of collateral and may, if it is large enough, relax the collateral constraint. This is the ex post credit channel of monetary policy ${ }^{18}$. Second, and more interestingly, a monetary restriction ex ante (in period 0) can reduce the accumulation of corporate debt $D$. This is the ex ante credit channel of monetary policy. Indeed, containing firms' debt burden is the purpose of a proactive monetary policy in our framework. For simplicity, we abstract from the ex post channel by assuming that the ex post real price of collateral is exogenous to monetary policy. ${ }^{19}$

The probability that the economy falls in a credit crunch is a measure of its financial fragility. We denote this probability by $\mu$. It is equal to the probability that the price of collateral falls below the threshold defined in equation (4):

$$
\mu=\operatorname{Pr}\left[Q_{1}<\gamma+(1+r) D\right]
$$

The probability of a credit crunch is increasing with the ex post debt burden, $(1+r) D$. In turn, the level of firms' borrowing in period $0, D$, is a decreasing function of $r$. For a monetary restriction in period 0 (a rise in $r$ ) to reduce the probability of a credit crunch, the debt burden $(1+r) D$ must be decreasing with $r$. That is, the semi-elasticity of firms' borrowing with respect to the real interest rate should be lower than -1 . The model in the appendix satisfies this property, since it yields the expression:

$$
(1+r) D=E_{0}\left(Q_{1}\right)-(1+r) K
$$

\footnotetext{
${ }^{18}$ Note that if corporate debt were nominal, the ex post credit channel would involve another effect. A monetary expansion would contribute to relax the collateral constraint by inflating away a fraction of the debt.

19 This result is obtained, in the micro-founded model, by assuming that households' utility is linear in period 1 .
} 
where $K$ is the level of firms' equity. The debt burden is linearly increasing with the expected price of collateral, and linearly decreasing with the real interest rate. Hence we have that the probability of a credit crunch is decreasing with the ex ante real interest rate:

$$
\frac{\partial \mu}{\partial r}<0
$$

This result is central to our analysis: a preemptive monetary restriction at period 0 reduces the risk of a credit crunch at period 1 . The monetary restriction reduces the debt accumulated by firms, and so makes them more resilient to negative shocks in the price of collateral.

\subsection{Reactive and proactive monetary policies}

As noted earlier, the difference between our model and the standard textbook model is that the distribution of supply shocks at period 1 is endogenous to monetary policy at period 0 . We call a proactive monetary policy a policy that is geared towards avoiding a credit crunch in period 1. This is by contrast with a reactive policy, that simply responds to a credit crunch if it occurs - making no difference between a credit crunch and a standard supply shock.

A pro-active monetary policy involves a trade-off between the level of output in period 0 and the risk of a credit crunch in period 1 . The risk of a credit crunch can be reduced by a monetary restriction, but this restriction also depresses output and prices in period 0 , since:

$$
\begin{aligned}
& y_{0}=-\sigma r \\
& p_{0}=-\sigma r / \alpha
\end{aligned}
$$

By contrast with a reactive monetary policy, a proactive monetary policy is determined in the context of a trade-off between period 0 policy objectives in terms of output and prices, and the risk of a credit crunch in period 1.

In order to investigate this trade-off one has to endow the monetary authorities with an intertemporal objective function. We assume that the government minimizes the following quadratic loss function:

$$
L=\sum_{t=0,1}\left(p_{t}^{2}+\omega y_{t}^{2}\right)
$$

\subsection{A non-conventional, non-linear Taylor rule}

We now illustrate the difference between proactive and reactive monetary policies with a specification of the model that draws on the recent debates on the "New Economy" and the stock market. Assume that in the second period, the price of collateral can take two values, a 
high level, $Q_{H}$, corresponding to the "New Economy" scenario, and a low level, $Q_{L}$, corresponding to the "Old Economy" scenario. Viewed from period 0, the probability of the "New Economy" scenario is a measure of the optimism of economic agents. We denote it by $P_{N E}$, and by $P_{O E}=1-P_{N E}$ the probability of the Old Economy scenario.

The realization of the "Old Economy" scenario is associated with a fall in asset prices and possibly, a credit crunch. By equation (4), a credit crunch occurs in the event of the realization of the "Old Economy" scenario if $Q_{L}<(1+r) D+\gamma$. Substituting out $D$ with equation (6) and noting that $E_{0}\left(Q_{1}\right)=P_{N E} Q_{H}+\left(1-P_{N E}\right) Q_{L}$, the condition for a credit crunch can be written

$K(1+r)<\gamma+P_{N E} \cdot\left(Q_{H}-Q_{L}\right)$

A credit crunch is more likely to occur ex post if private agents are more confident in the "New Economy" ex ante ( $P_{N E}$ is large), because firms borrow more. It is also more likely if the asset price differential between the "New Economy" and the "Old Economy" is large.

The authorities can maintain the probability of a credit crunch at its minimum level of 0 by setting the first period real interest rate at the following level:

$$
1+r=\frac{\gamma+P_{N E} \cdot\left(Q_{H}-Q_{L}\right)}{K}
$$

This rule implies that the monetary authorities should respond to rising confidence in the "New Economy" (an increase in $P_{N E}$ ) by restricting monetary policy (raising $r$ ).

Note the difference with standard rules, such as the Taylor rule. Standard rules make the monetary authorities respond to the current or expected levels of macroeconomic variables such as the output gap or the inflation rate. The rule above suggests that the monetary policymaker should respond to prospective developments in asset markets, for which macroeconomic aggregates do not provide appropriate summary statistics.

It is not clear, however, that the authorities always wish to reduce the probability of a credit crunch to zero. The required level of the real interest rate may be excessively high. There is a threshold $\bar{r}$ above which the authorities prefer to take the risk of a credit crunch, and respond ex post if need be- that is, to be reactive rather than proactive.

By adopting a reactive approach, the government can set its loss to zero in the first period, but takes the risk of incurring a strictly positive loss in the second period if a credit crunch occurs. In the latter case the authorities minimize the loss function $p_{2}{ }^{2}+\omega y_{2}{ }^{2}$ under the constraint $y_{2}=\alpha p_{2}-v$. The solution is $p_{2}=\omega \alpha v /\left(1+\omega \alpha^{2}\right), y_{2}=-v /\left(1+\omega \alpha^{2}\right)$ and the loss is equal to $\omega v^{2} /\left(1+\omega \alpha^{2}\right) .^{20}$ The intertemporal loss is equal to the probability of a credit crunch, $P_{O E}$, times the loss conditional on a credit crunch

${ }^{20}$ The credit crunch increases the price level because it reduces supply without changing demand. If firms used variable production inputs other than labor-or if households were 
$L_{\text {reactive }}=P_{O E} \frac{\omega v^{2}}{1+\omega \alpha^{2}}$.

By contrast, if the government raises the real interest rate to the level implied by (12) in order to avoid a credit crunch, ouput and prices are depressed below the target levels in period 1. One has $y_{1}=-\sigma r, \quad p_{1}=-\sigma r / \alpha$, so that the authorities have to suffer a loss of

$$
L_{\text {proactive }}=\left(1+\omega \alpha^{2}\right)\left(\frac{\sigma r}{\alpha}\right)^{2} \text {. }
$$

The government adopts a proactive policy if $L_{\text {proactive }}<L_{\text {reactive }}$. Simple computations show that this is the case if the real interest rate required by a proactive policy is not too high:

$$
r \leq \bar{r} \equiv \frac{\alpha}{\sigma} \frac{v}{1+\omega \alpha^{2}} \sqrt{\omega P_{O E}}
$$

The maximum real interest rate that the government is ready to bear in order to forestall a credit crunch is increasing with the probability of a credit crunch, $P_{O E}$, and with the output cost of a credit crunch, $v$. It is decreasing with the sensitivity of output to the real interest rate, $\sigma$.

Figure 13 illustrates how the optimal monetary policy depends on the optimism of the private sector. It shows how the real interest rate $r$, the first-period level of output and prices, $y_{0}$ and $p_{0}$, and the level of domestic credit $D$, depend on the probability of realization of the "New Economy" scenario. The figure was constructed for the following values of the parameters: $Q_{H}=100, Q_{L}=75, \quad K=75, \quad \gamma=200 / 3, \quad \alpha=1 / 2, \sigma=1 / 4, \omega=1 / 2, v=10 \%$. The price of collateral is 25 percent lower in the "Old Economy" scenario than in the "New Economy" one. A credit crunch is associated with a 10 percent drop in output. The elasticity of first-period output with respect to the real interest rate is 0.25 (i.e., a 1 percent rise in the real interest rate depresses first-period output by 0.25 percent).

As the private sector's optimism increases, the economy goes through three different phases. First, if $P_{N E}$ is low (lower than 33 percent in the figure), firms' borrowing is sufficiently low that the realization of the "Old Economy" scenario is not associated with a credit crunch. In this case, the government adopts a reactive policy because there is no reason to be proactive. If $P_{N E}$ takes intermediate values (between 33 and 60 percent in the figure), the government restricts monetary policy in a proactive way. Finally, if $P_{N E}$ is high, the government reverts to a reactive stance, even though there is a risk that the economy falls in a credit crunch. The

credit constrained - the credit crunch would also reduce demand (making the model more consistent with the evidence that busts are deflationary, see figures 11 and 12). 
reason is that, given the private sector's high level of optimism, the government would have to raise the real interest rate to an excessive level in order to insure the economy against a credit crunch. At the same time, the benefit of the proactive policy is lower since the credit crunch is less likely to occur. Leaning against the market has higher costs and lower benefits. The proactive policy dominates for intermediate levels of "market exuberance".

The model highlights both the potential benefits and the limits of a proactive monetary policy. It may be optimal, in some circumstances, to sacrifice some output in order to reduce the risk of a collateral-induced credit crunch. However, there are also circumstances in which the domestic authorities are better off accepting the risk of a credit crunch (i.e., a reactive policy). Whether the authorities should in practice engage in a proactive policy at a particular time is contingent on many factors, and is a matter of judgment. In our model, the optimal monetary policy depends on the observable macroeconomic variables, and on the private sector's expectations, in a highly non-linear way. This suggests to us that the optimal monetary policy probably does not take the form of a simple mechanical rule such as the Taylor rule, even if it is augmented by a linear term in asset prices. Which form it should take in practice is difficult to assess on the basis of our very stylized model. Further theoretical and empirical work is needed before we can assess with some confidence the scope for proactive monetary policies.

\section{$\underline{4.5}$ Irrational exuberance}

To conclude this section, let us re-emphasize that our analysis of proactive monetary policy is not premised on the assumption that asset prices deviate from their fundamental values. The essential variable, from the point of view of policymaking is the risk of a credit crunch induced by an asset market reversal. This assessment can be made based on the historical record (as illustrated in sections 2 and 3), as well as information specific to each episode. In particular, the suspicion that an asset market boom is a bubble which will have to burst at some point is an important input in this assessment. However, bubbles are not of the essence of the question since, as our model shows, the question would arise even in a world without bubbles. Hence, the debate about proactive versus reactive monetary policies should not be reduced to a debate over the central bank's ability to recognize a bubble when it sees one.

Going back to our model, the notion of irrational expectations can be captured by assuming that private agents base their decisions, in period 0 , on an excessively optimistic assessment of the probability of the "New Economy" scenario. Let us assume that firms borrow in period 0 on the basis of a probability $P_{N E}^{\prime}$ which is larger than the true probability $P_{N E}$. The monetary authorities base instead their policy on the true probability.

Figure 14 shows the optimal monetary policy as a function of the private sector's optimism (measured by $P_{N E}^{\prime}$ ), assuming that the monetary authorities keep their own estimate at $P_{N E}=0.1$. Otherwise, the calibration is the same as in Figure 13. The real interest rate required by the proactive monetary policy is exactly the same as before, since it is dictated by the expectations of the market, not those of the central bank. However, the proactive monetary policy is maintained for higher levels of market optimism than before, because this optimism is 
not shared by the monetary authorities. Hence irrational exuberance broadens the scope for proactive monetary policy.

\section{$\underline{\text { Section 5. Conclusions and Policy Implications }}$}

The analysis in this paper suggests that boom-busts in asset prices can be very costly in terms of declining output. This was clearly the case in the U.S. Great Depression and in the recent Japanese experience. We also argue that there is a case under certain circumstances to use monetary policy in a proactive way to restrict private domestic credit and diffuse an asset price boom to prevent a credit crunch.

The consensus view among policy makers today however, is not to pursue such a course but rather to follow a reactive policy and deal with the consequences of an asset price bust after it happens. Our paper we believe suggests that the case for a proactive policy is a real issue - that the current strategy of following a Taylor rule that focuses the policy instrument exclusively on deviations from inflation forecasts and the output gap - and then injecting liquidity ex post in the event of a credit crunch, may in certain circumstances be more costly in terms of lost output than a proactive policy incorporating asset prices directly into the central bank's objective function. In a sense had the Federal Reserve followed the views of Strong and later Harrison and defused the stock market boom in 1928 rather than following the policies that it did, the outcome would have been very different. A similar conjecture could be made about the Bank of Japan's policy in the late 1980s.

Our analysis in this paper should be interpreted as being mainly suggestive because we do not provide empirical estimates of the magnitude of the output losses under the alternative policy strategies. To do this would require either simulating the effects of alternative policy rules in an econometric model or in a calibrated dynamic general equilibrium model that would involve the kind of non-linearity we have emphasized in this paper. These are topics for future research.

Finally the descriptive evidence that we present shows that stock market boom-busts are rare events, whereas property boom-busts are quite frequent. This suggests prima facie that the case for a proactive policy may be more telling to deal with property price credit crunches. Since these events occur quite regularly in the smaller countries of Europe this issue may pose a challenge for the ECB which sets its policy based primarily on Europe wide objectives. 


\section{REFERENCES}

Batini, Nicoletta, and Edward Nelson, 2000, "When the Bubble Bursts: Monetary Policy Rules and Foreign Exchange Market Behavior," mimeo, Bank of England, London.

Bayoumi, Tamim, and Charles Collyns, 2000, Post-Bubble Blues: How Japan Responded to Asset Price Collapse (Washington: International Monetary Fund).

Bernanke, Ben, 1983, "Non-monetary Effects of the Financial Crisis in the Propagation of the Great Depression," American Economic Review Vol. 73, pp. 257-71. , and Mark Gertler, 1989, "Agency Costs, Net Worth and Business Fluctuations," American Economic Review Vol.. 79, pp. 14-31. , and Mark Gertler, 2000, "Monetary Policy and Asset Price Volatility," NBER Working Paper No. 7559. , and Mark Gertler, 2001, "Should Central Banks Respond To Movements in Asset Prices?” American Economic Review, Papers and Proceedings, pp.253-257.

Bordo, Michael D, Takatoshi Ito, and Tokuo Iwaisako, 1997, "Banking Crisis and Monetary Policy: Japan in the 1990s and the U.S. in the 1930s," University of Tsukuba (mimeo).

Cecchetti, Stephen B, Hans Genberg, John Lipsky, and Sushil Wadhwami, 2000, Asset Prices and Central Bank Policy (London: International Center for Monetary and Banking Studies).

Collyns, Charles, and Abdejhak Senhadji, 2002, "Lending Booms, Real Estate, Bubbles and the Asian Crisis.” IMF Working Paper 02/20 (Washington: International Monetary Fund).

Drees, Buckhard, and Ceyla Pazarbasioglu, 1998, The Nordic Banking Crises: Pitfalls in Financial Liberalization? IMF Occasional Paper No. 161 (Washington: International Monetary Fund).

Eichengreen, Barry, and Michael D. Bordo, 2002, "Crises Now and Then: What Lessons from the Last Era of Financial Globalization,” NBER Working Paper No. 8716.

Filardo, Andrew J, 2000, "Monetary Policy and Asset Prices," Federal Reserve Bank of Kansas City Review, Vol. 85, No. 3.

Fisher, Irving, 1933, Debt deflation, New York.

Friedman, Milton and Anna J. Schwartz, 1963, A Monetary History of the United States 1867 to 1960 (Princeton: Princeton University Press, New Jersey). 
Galbraith, John, 1958, The Great Crash (Boston, Houghlin Mifflin).

Garber, Peter, 2000, Famous First Bubbles: The Fundamentals of Early Manias (Cambridge: MIT Press).

Hart, Oliver and John Moore, 1994, "A Theory of Debt Based on the Inalienability of Human Capital," Quarterly Journal of Economics 109(4), pp.841-79.

International Monetary Fund, 2000, World Economic Outlook, Chapter III, May 2000: Asset Prices and the Business Cycle (Washington).

Iwaisako, Tokuo and Takatisho Ito, 1995, "Explaining Asset Bubbles in Japan,” NBER Working Paper No. 5350.

Kanaya, Akihiro and David Woo, 2000, "The Japan Banking Crisis of the 1990s: Sources and Lessons," IMF Working Paper 00/7 (Washington: International Monetary Fund).

Kindleberger, Charles, 1989, Manias, Panics and Crashes, (Revised Edition New York Basic Books).

Kiyotaki, Nobuhiro and John Moore, 1997, “Credit Cycles," Journal of Political Economy, Vol. 105 (2), pp. 211-48.

Meltzer, Allan, 2002 (forthcoming), A History of the Federal Reserve, (Chicago: University of Chicago Press).

Mishkin, Frederick S. and Eugene White, 2002, "U.S. Stock Market Crashes and their Aftermath: Implications for Monetary Policy” Rutgers University (mimeo) February.

Romer, Christina, 1990, "The Great Crash and the Onset of the Great Depression," Quarterly Journal of Economics, Vol.105 (August) pp. 597-624. , 1992 “What Ended the Great Depression?” Journal of Economic History, Vol. 52, pp. 757-84.

Schinasi, Garry and Monica Hargreaves, 1993, "Boom and Bust in Asset Markets in the 1980s: Causes and Consequences" in Staff Studies For the World Economic Outlook, (Washington)

White, Eugene N., 1990, “The Stock Market Boom and Crash of 1929 Revisited,” Journal of Economic Perspectives Vol.4 (2), Spring, pp. 67-83. ,2000, "Banking and Finance in the Twentieth Century," in Stanley Engerman and Robert Gallman, eds., The Cambridge Economic History of the United States, Vol. III (Cambridge: Cambridge University Press) pp. 743-802. 


\section{APPENDIX}

The model has three periods $t=0,1,2$ (one period more than the reduced-form model). The last period is added so as to endogenize the price of the asset. There are two types of private agents: households and entrepreneurs. There is a continuum of mass 1 of each type. Households supply labor and funds to entrepreneurs, who produce an homogeneous consumption good. We assume that there is a fixed quantity of productive capital in the economy. Capital does not depreciate and it cannot be reproduced. Productive capital can be though of as "land", and the consumption good as "fruit".

Households are identical and live for three periods. Their intertemporal utility is given by:

$$
U^{h}=u\left(C_{0}\right)+C_{1}+C_{2}
$$

where $C_{t}$ denotes the representative household's consumption of fruit, and $u(\cdot)$ is increasing and concave.

Entrepreneurs live in the first two periods $t=0,1$. They have a native ability to combine land with labor to produce fruit. We assume that each entrepreneur operates exactly one unit of land. When combined with $L_{t}$ units of labor, one unit of land yields:

$$
y_{t}=L_{t}^{1-\eta}, \quad t=0,1,
$$

units of $\operatorname{good}(\eta \in(0,1))$.

We assume that in the last period entrepreneurs are no longer required in the production process. The production process in period 2 is the same as in Lucas' "tree economy": each unit of land yields an exogenous quantity of good, denoted by $R$. This assumption captures the idea that in the long run the economy reaches a state of equilibrium where the type of financial disruption that we focus on no longer matters. Variable $R$ may be interpreted as the long-run productivity of capital. Its value is unknown at time 0 and is revealed at time 1 .

At time 0 the productive asset (land) is owned by households. The entrepreneurs must take possession of the asset in order to produce but they do not have enough cash. We assume that the entrepreneurs finance the purchase of the asset by issuing debt. Let $Q_{0}$ be the real price of the asset in period 0 . At the beginning of period 0 each entrepreneur is endowed with $K$ and borrows $D=Q_{0}-K$.

Entrepreneurs produce in periods 0 and 1 . We assume that in period 1, entrepreneurs must borrow "inside the period" to finance working capital. This can be justified by the fact that inside the period, production takes time, and some production inputs that are immobilized in the production process must be financed by credit. The entrepreneurs that do not manage to obtain the intra-period credit are inactive - they do not produce. In general the intra-period credit requirement could differ across entrepreneurs, for example because of idiosyncratic shocks in the production process. The real value of the credit required by entrepreneur $j$ is denoted by $\gamma(j)$.

We further assume that entrepreneurs' debt is subject to a re-negotiation problem a la Hart and Moore (1994) and Kiyotaki and Moore (1997). An entrepreneur has the option to walk away with the output after production has taken place, leaving the asset for his creditors to seize. The entrepreneur walks away after production has taken place in period 1 if and only if his total debt (the repayment of the period 0 loan contracted to purchase the productive asset, plus the intra-period credit) exceeds the value of collateral. If creditors anticipate that the entrepreneur will default they do not provide the intra-period credit and the entrepreneur cannot operate. Hence the entrepreneur can operate if and only if the required intra-period credit is lower than the net value of the firm, i.e. if:

$\gamma(\mathrm{j})<\mathrm{Q}_{1}-(1+\mathrm{r}) \mathrm{D}$ 
At the level of the entrepreneur, this constraint is of the "all-or-nothing" type. If it is not satisfied the entrepreneur is simply inactive and the asset is sold at the end of the period. If it is satisfied the entrepreneur operates free of credit constraint. We assume that the proceeds of the sale are always sufficient to repay the period 0 lenders (i.e., $\left.Q_{1} \geq(1+r) D\right)$, so that there is no default risk in equilibrium.

One has to make an assumption on the distribution of the intra-period credit requirement across entrepreneurs. For simplicity we assume that there are two types of entrepreneurs: some need a level $\gamma$ of intra-period credit and the others do not need intra-period credit at all. Denoting by $\phi$ the fraction of entrepreneurs of the first type, the number of active entrepreneurs at period $1, N_{1}$, is given by:

$$
\left\{\begin{aligned}
\mathrm{N}_{1} & =1 & & \text { if } \mathrm{Q}_{1}-(1+\mathrm{r}) \mathrm{D} \geq \gamma \\
& =1-\phi & & \text { if } \mathrm{Q}_{1}-(1+\mathrm{r}) \mathrm{D}<\gamma
\end{aligned}\right.
$$

In periods 0 and 1 , after production has taken place there is a financial market in which households exchange consumption good, money, IOUs, and the productive asset. For the sake of simplicity, we assume that entrepreneurs do not participate in the financial market. (This is necessarily true in period 1 because entrepreneurs consume their end-of-life wealth.) Hence in period 0 the real price of the asset results from the first-order conditions of the inter-temporal optimization problem of households

$Q_{0} u^{\prime}\left(C_{0}\right)=E_{0}\left(Q_{1}\right)$

$u^{\prime}\left(C_{0}\right)=1+r$

The utility function being linear in periods 1 and 2, the price of the asset at period 1 is simply equal to its final return:

$Q_{1}=R$

Money is used by households in periods 0 and 1. Money demand results from a cash-in-advance constraint:

$$
C_{t}=\frac{M_{t}}{P_{t}} \quad t=0,1
$$

The domestic government prints and transfers money to households in a lump-sum way. For simplicity we assume that the government makes the consumption of households equal to that of entrepreneurs by lump-sum transfers, so that the consumption of the representative households is proportional to aggregate output:

$$
C_{t}=\lambda Y_{t}
$$

(where $\lambda$ is equal to $1 / 2$ since there is the same number of entrepreneurs and households).

We assume that the nominal wage levels of periods 0 and $1, W_{0}$ and $W_{1}$, are preset at the beginning of period 0 , before $M_{0}$ and $M_{1}$ are known. For simplicity, we take the nominal wages as exogenous to the analysis.

The labor market is perfectly competitive. Aggregate supply at time $t$ is equal to the number of active entrepreneurs times the supply per active entrepreneur. An active entrepreneur produces $(W /(1-\eta) P)^{-(1-\eta) / \eta}$, while inactive entrepreneurs produce nothing. Hence aggregate supply can be written

$$
Y_{t}=N_{t} \cdot\left(\frac{1}{1-\eta} \frac{W_{t}}{P_{t}}\right)^{-\alpha}
$$


where $\alpha \equiv(1-\eta) / \eta$ is the elasticity of aggregate supply with respect to the real wage.

Leaving aside unimportant constants, the model can be written in log form like in the text (equation (2)), with $\varepsilon_{t}=\log N_{t}$. We have $\varepsilon_{t}=0$, except in period 1 if there is a credit crunch, in which case $\varepsilon_{1}=-v \equiv \log (1-\phi)$.

It results from $D=Q_{0}-K$ and the first-order conditions (A5)-(A6) that the debt burden in period 1 is:

$(1+r) D=E_{0}\left(Q_{1}\right)-K(1+r)$

(equation (6) in the text.)

We conclude by presenting a variant of the model in which credit crunches can be self-fulfilling, which gives scope for a form of lending-in-last-resort policy. Assume now that households' utility is concave in period 1 consumption, that is, equation (A1) is replaced by

$U^{h}=u\left(C_{0}\right)+u\left(C_{1}\right)+C_{2}$

The period 1 price of the asset must now satisfy

$Q_{1} u^{\prime}\left(C_{1}\right)=R$.

Substituting out $P_{1}$ from (A8) and (A10) and using $C_{1}=\lambda Y_{1}$, aggregate supply can be written as a function of the number of active firms

$Y_{1}=\kappa N_{1}^{1 /(1+\alpha)}$

where $\kappa \equiv \lambda^{1 /(1+\alpha)}\left(\frac{(1-\eta) M_{1}}{W_{1}}\right)^{\alpha /(1+\alpha)}$.

An equilibrium without $a$ credit crunch can coexist with an equilibrium with a credit crunch. To see this, let us denote by $Y^{H}$ and $Q^{H}$ the levels of output and asset price in the equilibrium without $a$ credit crunch and by $Y^{L}$ and $Q^{L}$ the analogs in the equilibrium with a credit crunch. One has $Y^{H}=\kappa>Y^{L}=\kappa(1-\phi)^{1 /(1+\alpha)}$ and $Q^{H}=R / u^{\prime}\left(\lambda Y^{H}\right)>Q^{L}=R / u^{\prime}\left(\lambda Y^{L}\right)$. Output and the price of the asset are both lower in the equilibrium with a credit crunch.

For both equilibria to exist one must have $Q^{H} \geq \gamma+(1+r) D>Q^{L}$. The price of collateral in the credit-crunch equilibrium must be sufficiently low so as to provoke a credit crunch, and sufficiently high in the no-credit-crunch equilibrium so as to avoid a credit crunch. The intuition behind the multiplicity involves the following vicious circle. A fall in the price of collateral reduces aggregate supply and consumption; households' attempt to sell the asset (in order to smooth consumption intertemporally) then depresses the price of the asset in equilibrium.

The bad equilibrium is removed if the monetary authorities peg the price of the asset at the good equilibrium level $Q_{1}^{H}$. This requires a promise by the monetary authorities to inject money into the economy would it threaten to switch to the bad equilibrium, a policy that can be interpreted as a form of lending-in-last-resort. 


\section{The United States}

Figure 1. Stock Price Index: Standard and Poor's 500, 1922-1941.

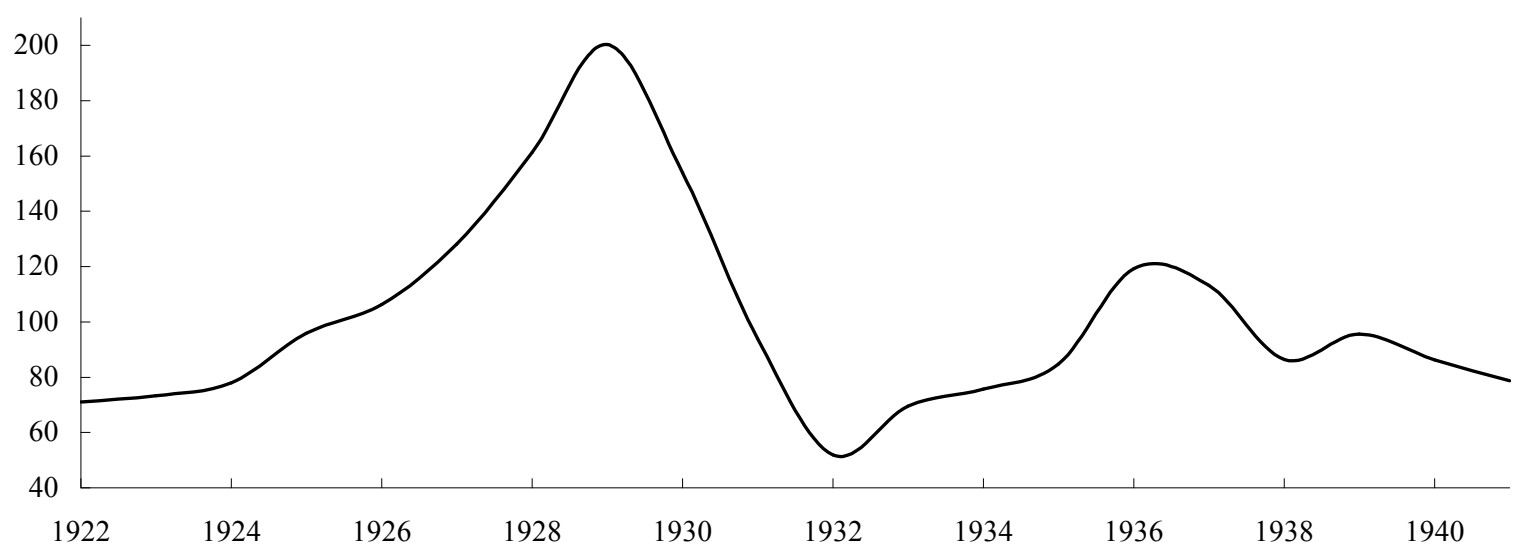

Source:

Historical Statistics of the United States: Millenial Edition (2003).

Figure 2. Agricultural Land Prices Per Acre, 1910-1945.

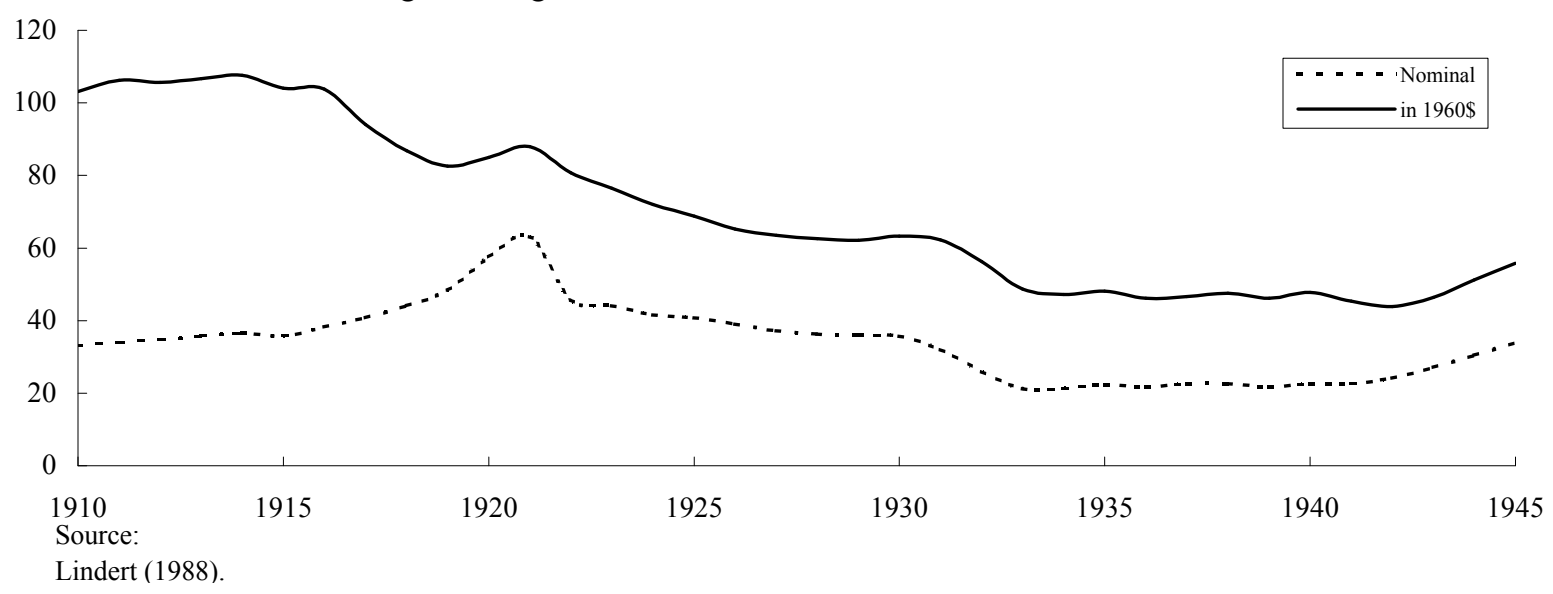

Figure 3. Bank Loans: Total, Secured by Securities, and Secured by Real Estate 1921-1941.

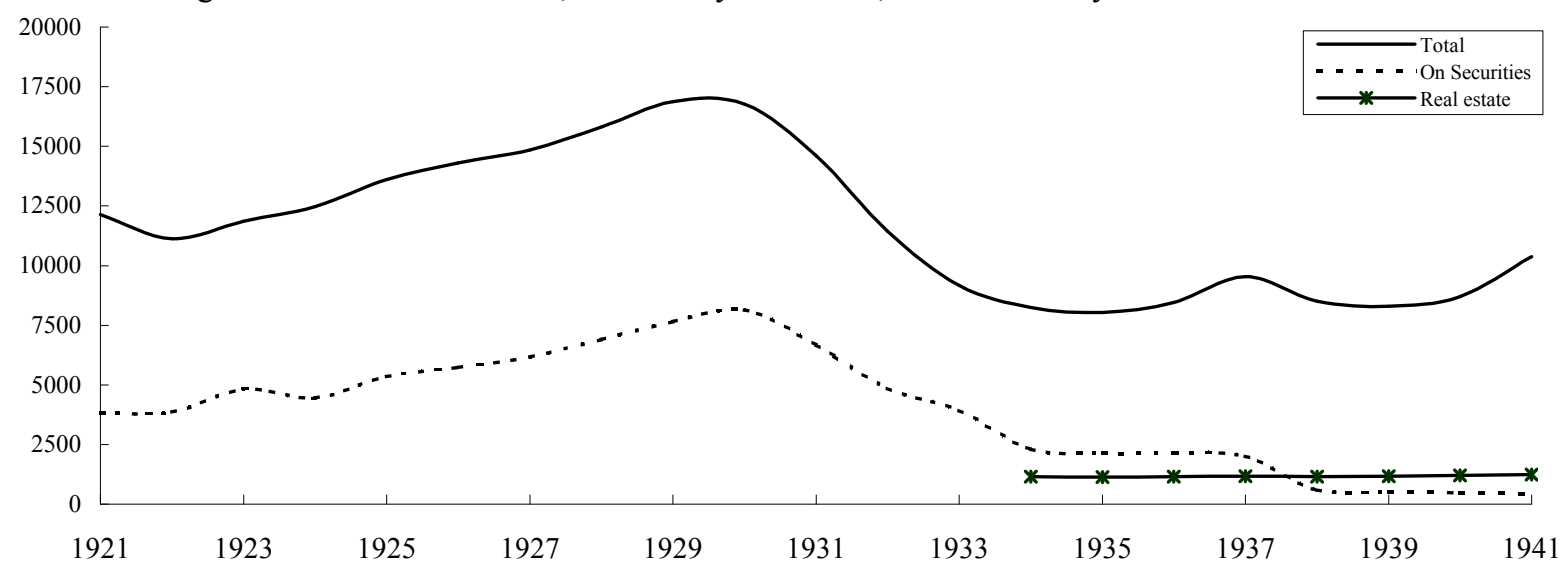

Source:

Federal Reserve Banking and Monetary Statistics (1943). 
Japan

Figure 4. Nominal Land Prices, 1980-1998.

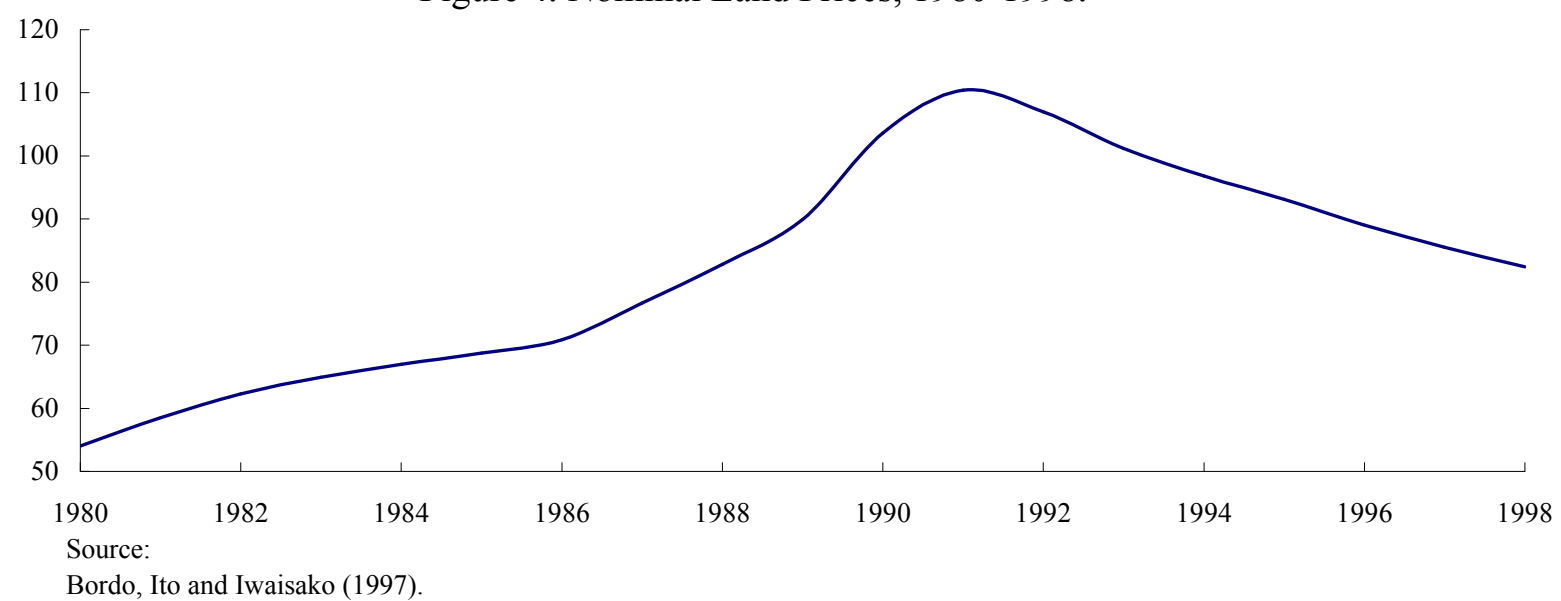

Figure 5. Stock Price Index: Nikkei, 1980-1998.

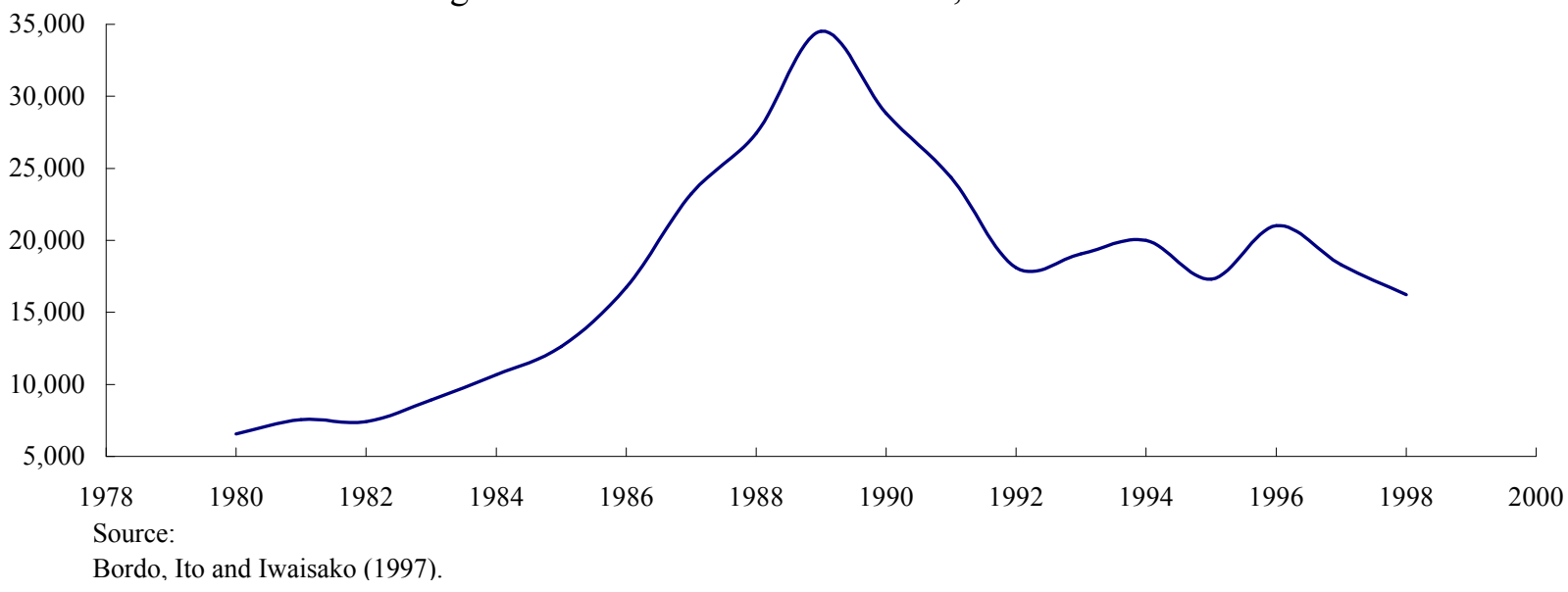

Figure 6. Bank Loans: Total, Secured by Securities and other Assets and Secured by Real Estate, 1982-

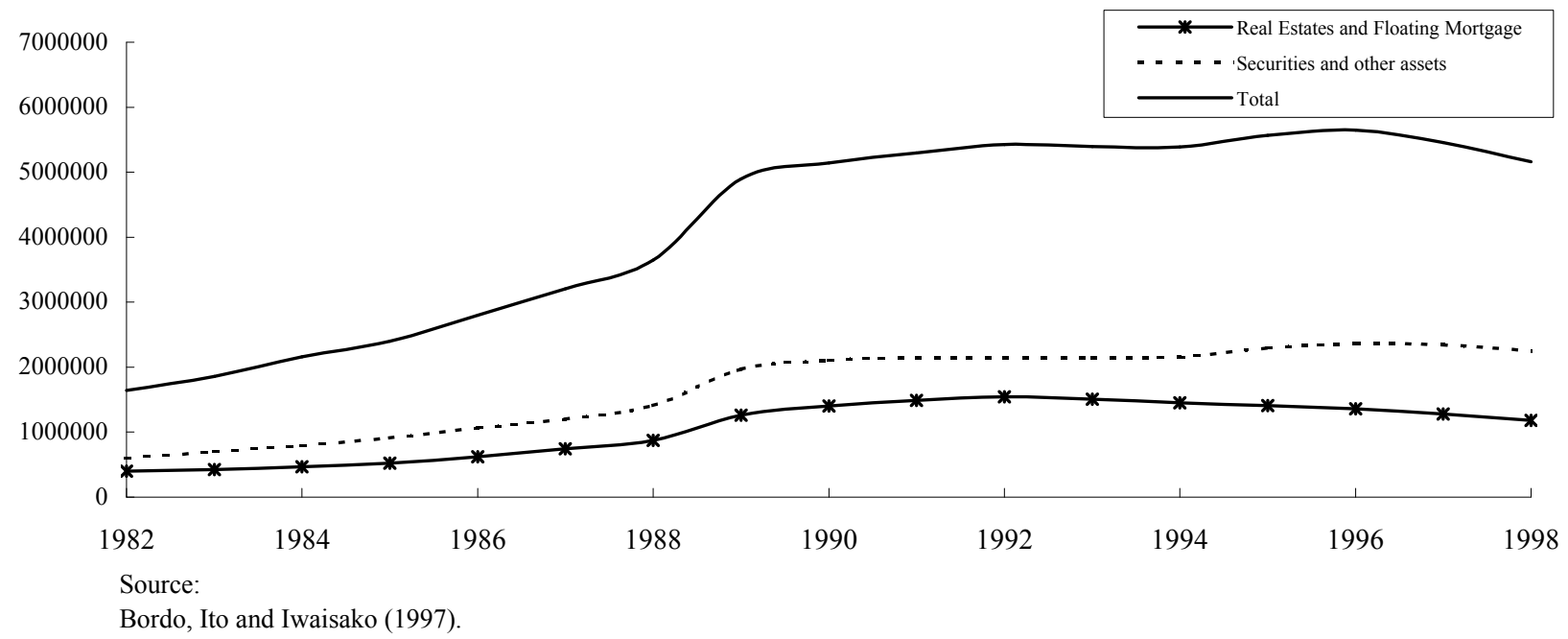


Figure 7. Boom-Bust in Residential Property Prices, 1970-1998 **
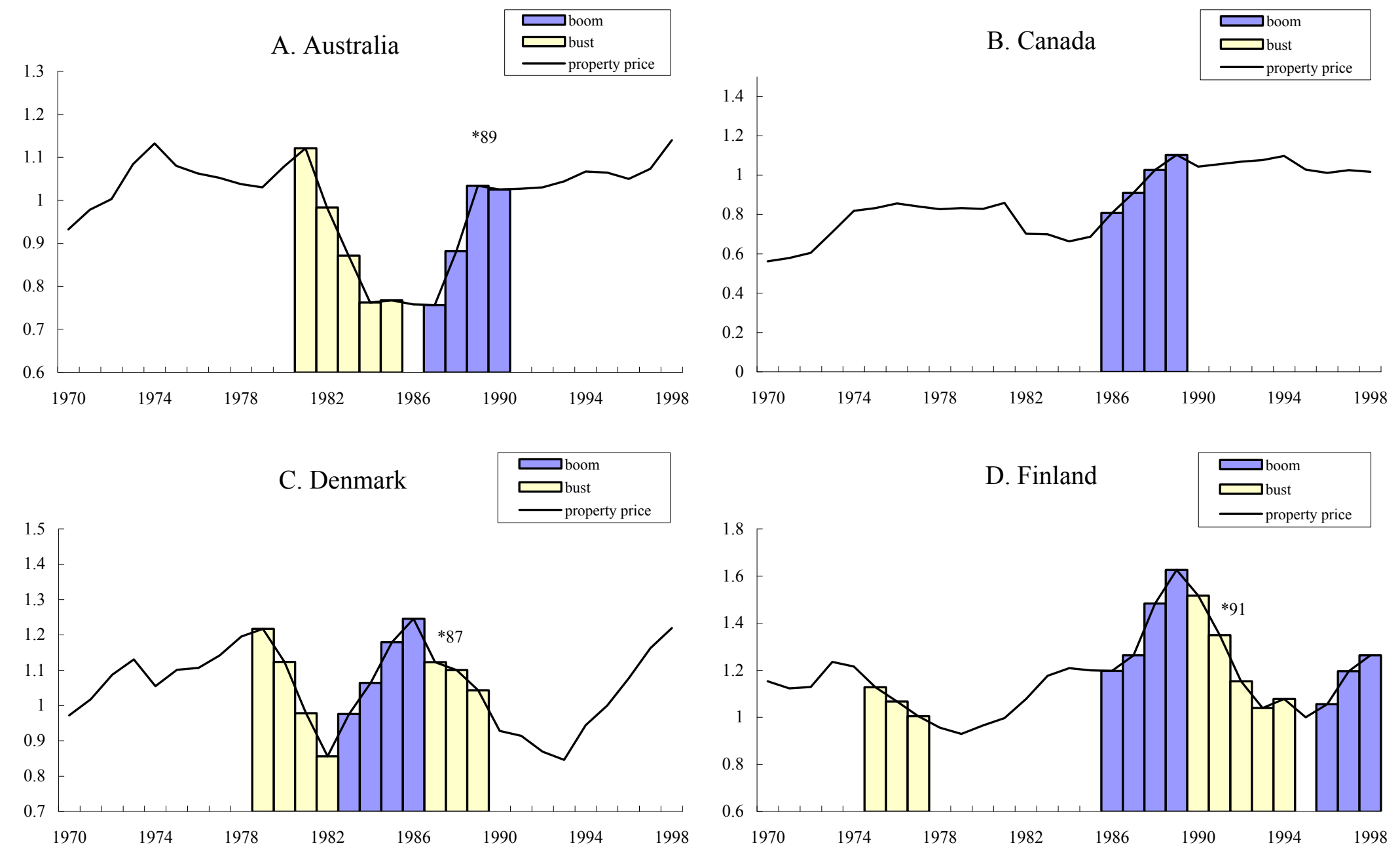

Sources:

Bank of International Settlements; International Financial Statistics and World Economic Outlook, International Monetary Fund.

*Banking crisis. See Eichengreen and Bordo (2002) Appendix A.

** Booms and busts are calculated by a three year moving average. 
Figure 7. Boom-Bust in Residential Property Prices, 1970-1998**
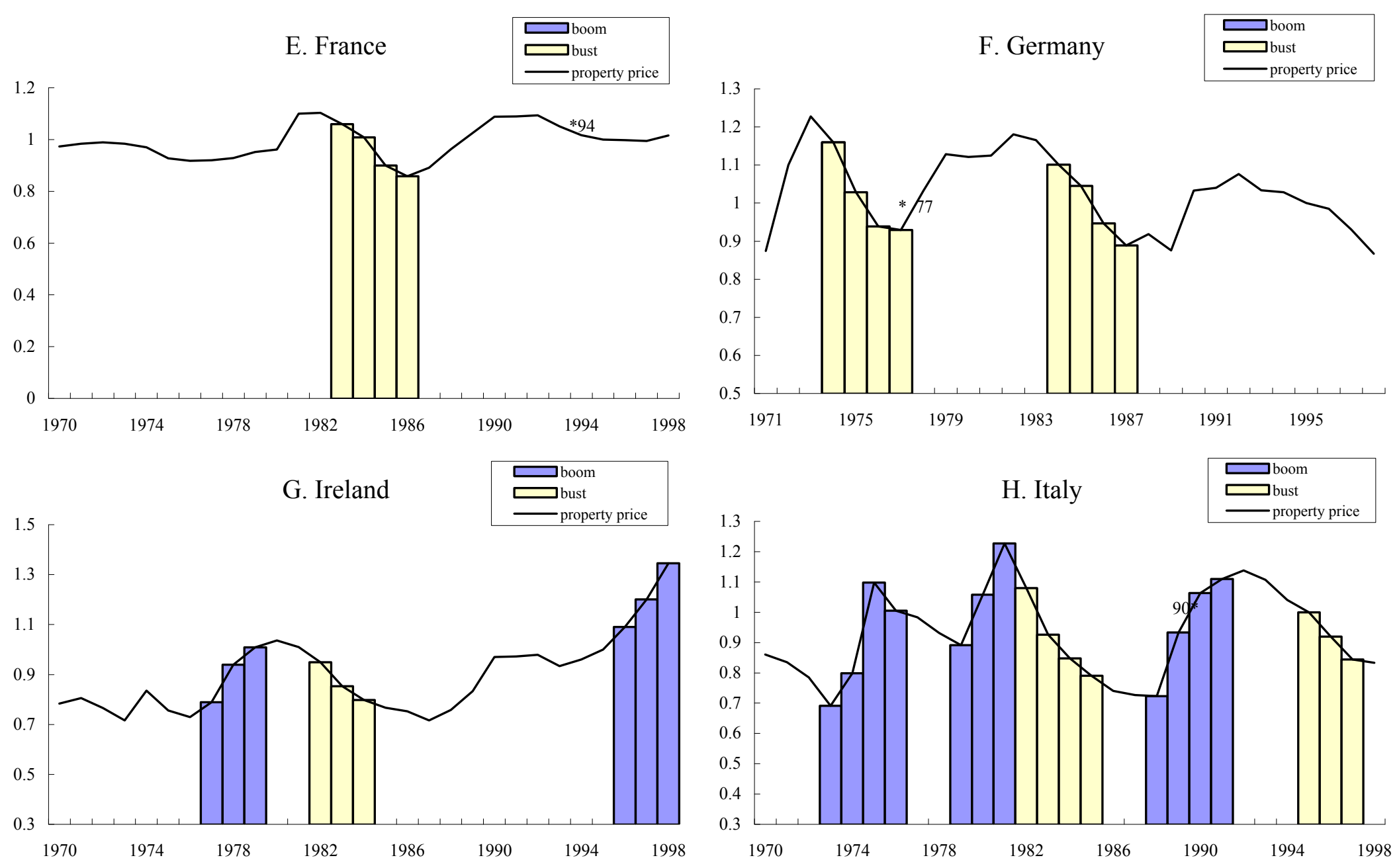

Sources:

Bank of International Settlements; International Financial Statistics and World Economic Outlook, International Monetary Fund.

*Banking crisis. See Eichengreen and Bordo (2002) Appendix A.

** Booms and busts are calculated by a three year moving average. The data starts in 1971 for Germany due to limited availability. 
Figure 7. Boom-Bust in Residential Property Prices, 1970-1998**
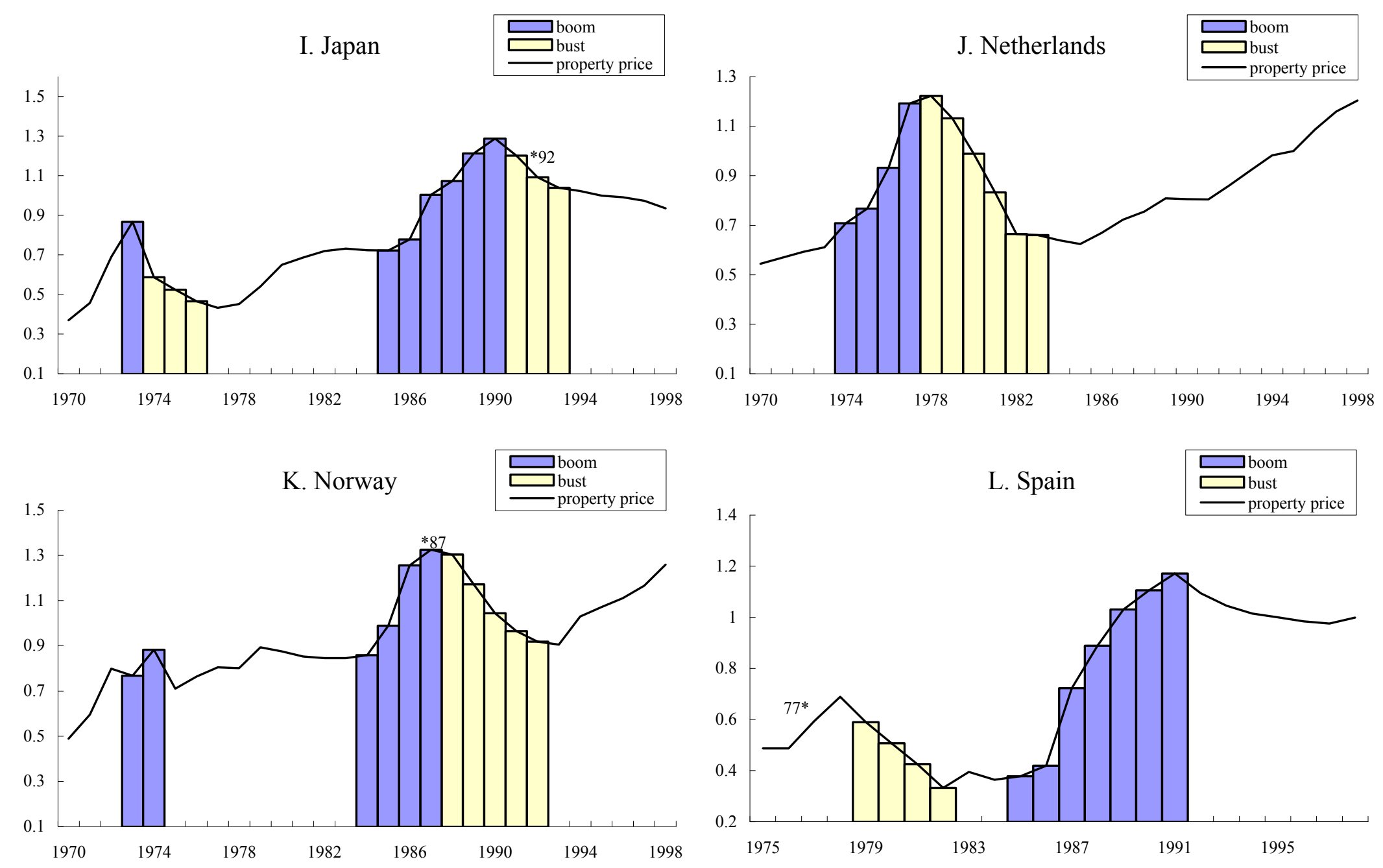

Sources:

Bank of International Settlements; International Financial Statistics and World Economic Outlook, International Monetary Fund.

*Banking crisis. See Eichengreen and Bordo (2002) Appendix A.

** Booms and busts are calculated by a three year moving average. The data starts in 1975 for Spain due to limited availability. 
Figure 7. Boom-Bust in Residential Property Prices, 1970-1998**
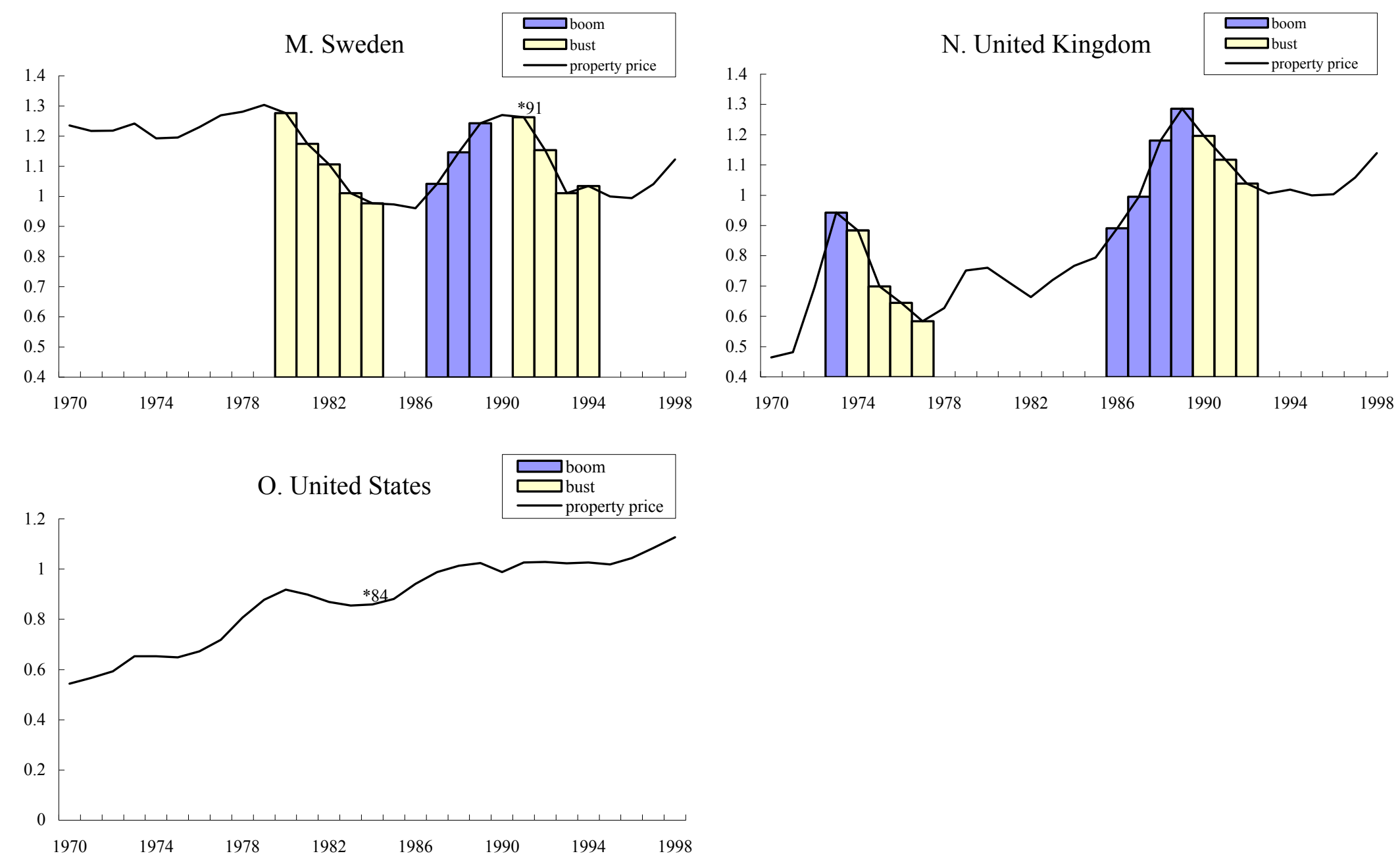

Sources:

Bank of International Settlements; International Financial Statistics and World Economic Outlook, International Monetary Fund.

*Banking crisis. See Eichengreen and Bordo (2002) Appendix A.

** Booms and busts are calculated by a three year moving average. 
Figure 8. Boom-Bust in Industrial Share Prices, 1970-2001**

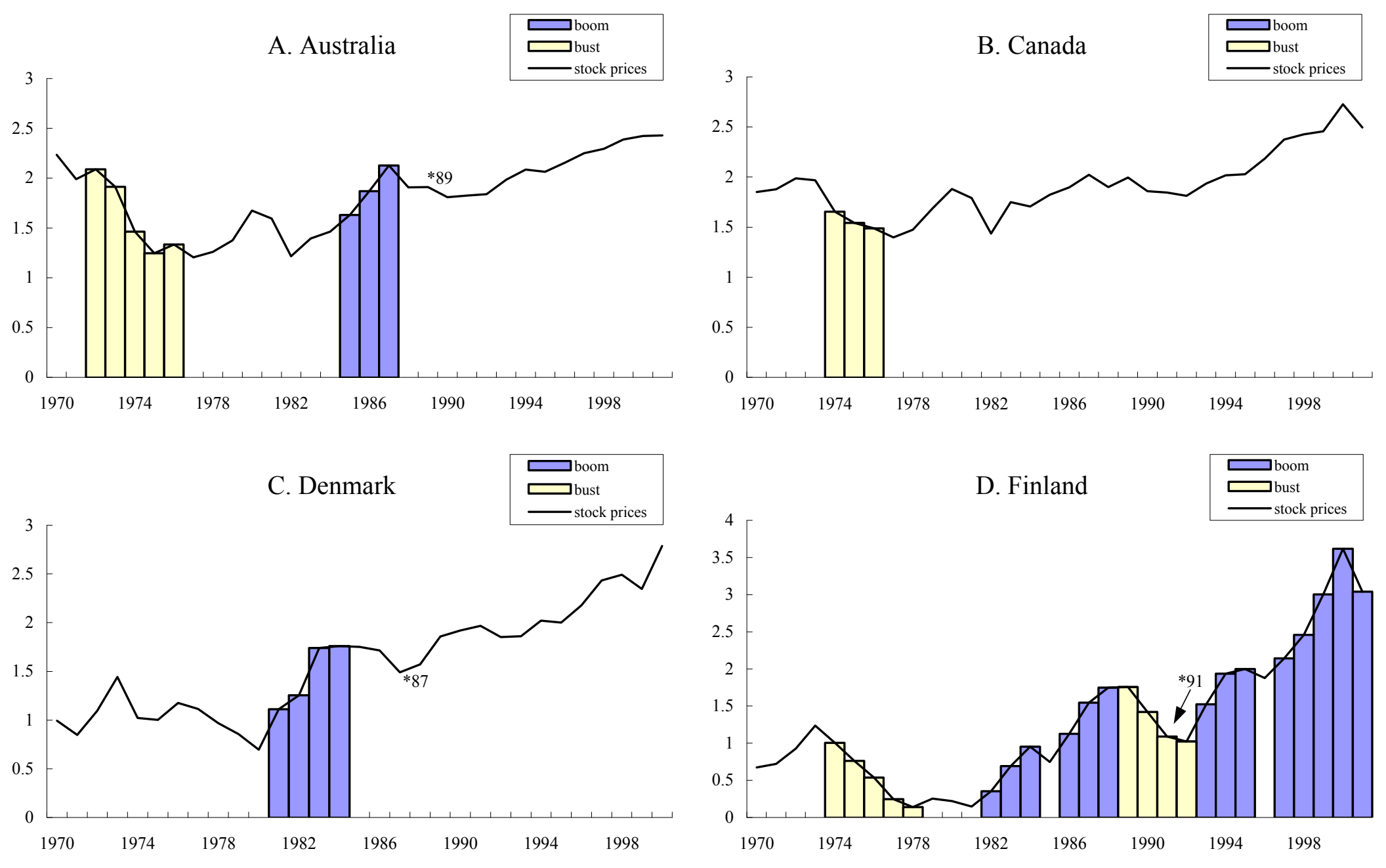

Sources:

International Financial Statistics, World Economic Outlook and country desks, International Monetary Fund.

*Banking crisis. See Eichengreen and Bordo (2002) Appendix A.

** Booms and busts are calculated by a three year moving average. The data ends in 2000 for Denmark due to limited availability. 
Figure 8. Boom-Bust in Industrial Share Prices, 1970-2001**
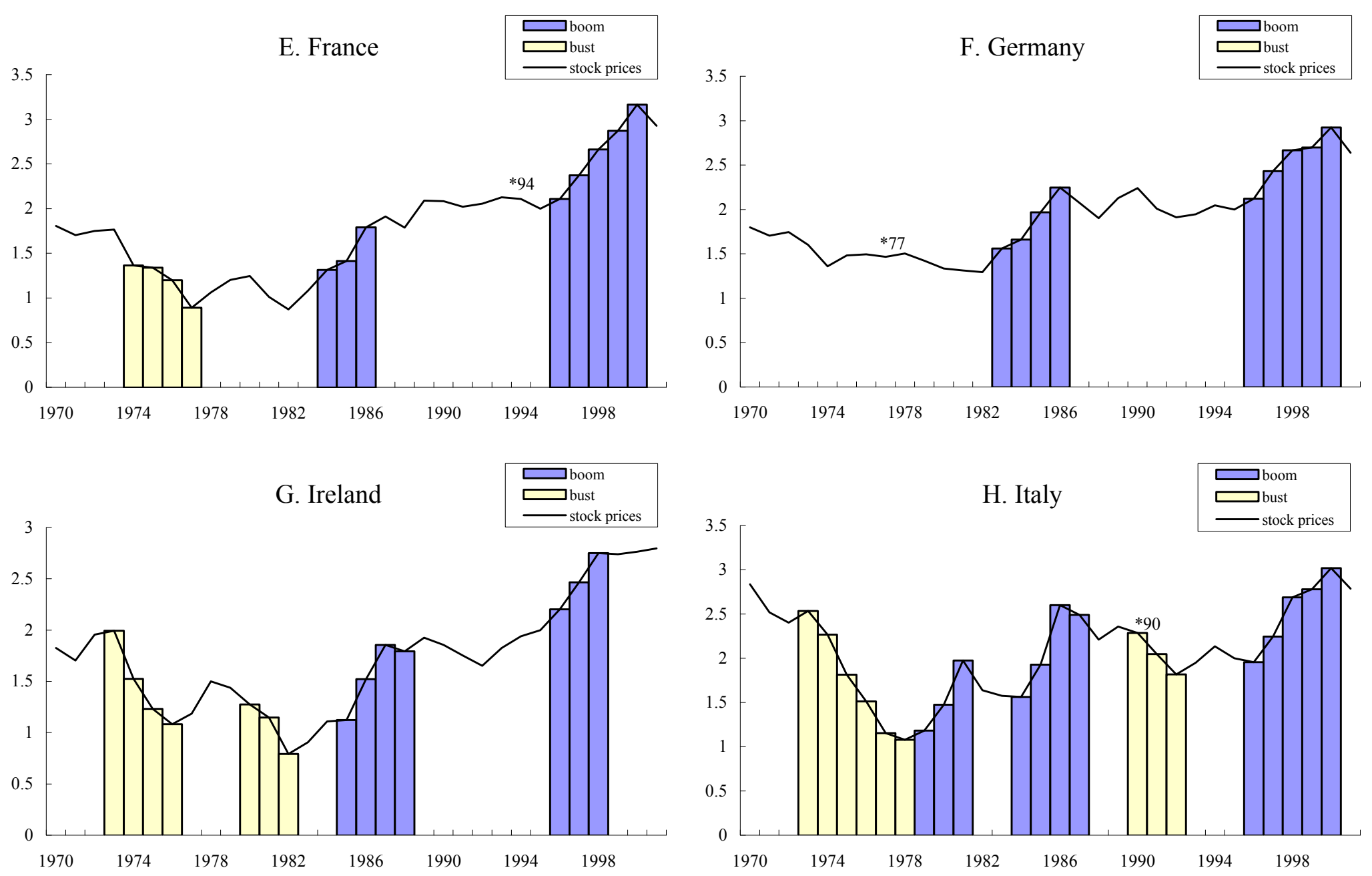

Source:

International Financial Statistics, World Economic Outlook and country desks, International Monetary Fund.

*Banking crisis. See Eichengreen and Bordo (2002) Appendix A.

** Booms and busts are calculated by a three year moving average. 
Figure 8. Boom-Bust in Industrial Share Prices, 1970-2001**
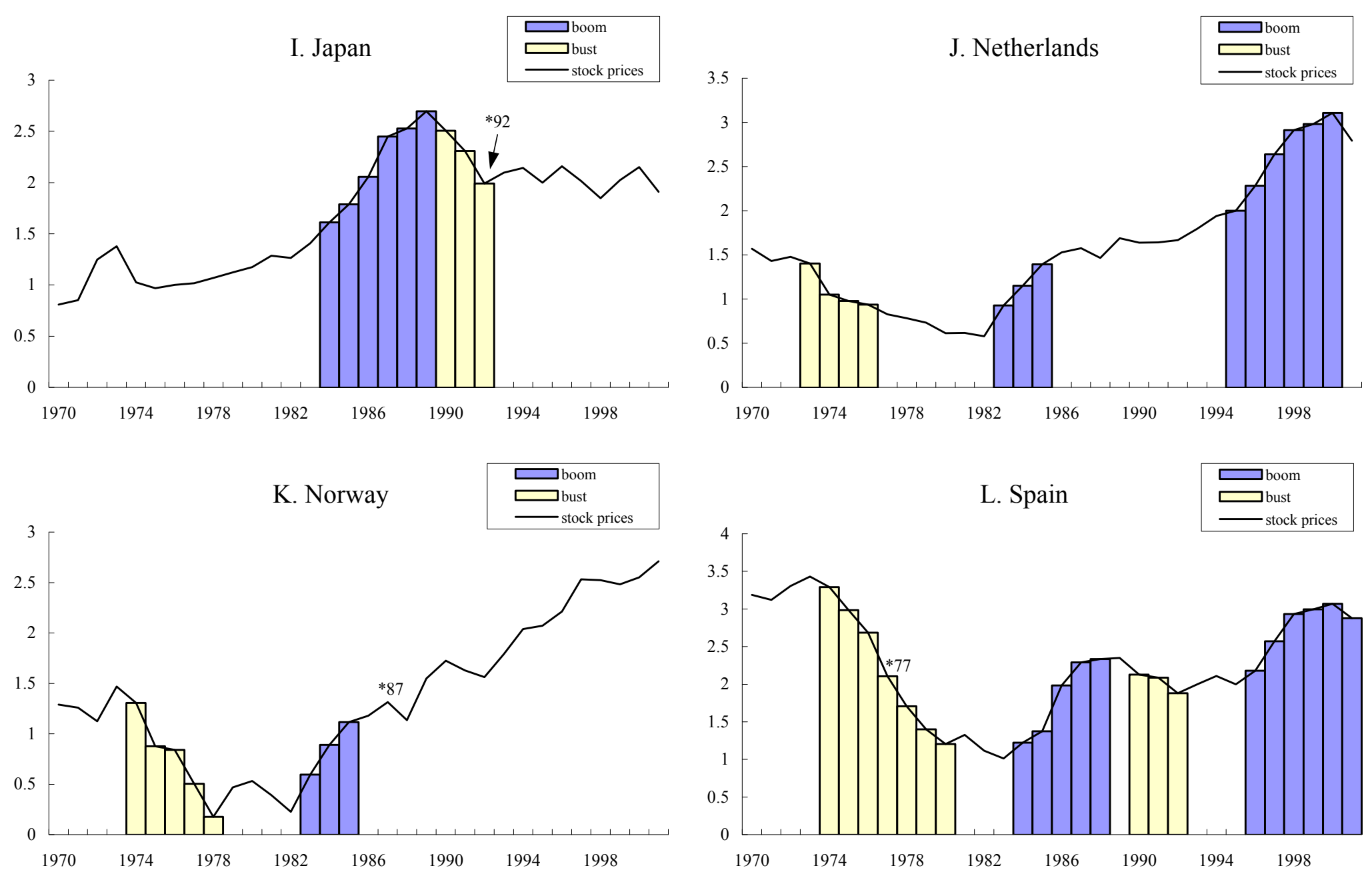

Source:

International Financial Statistics, World Economic Outlook and country desks, International Monetary Fund.

*Banking crisis. See Eichengreen and Bordo (2002) Appendix A.

** Booms and busts are calculated by a three year moving average. 
Figure 8. Boom-Bust in Industrial Share Prices, 1970-2001**
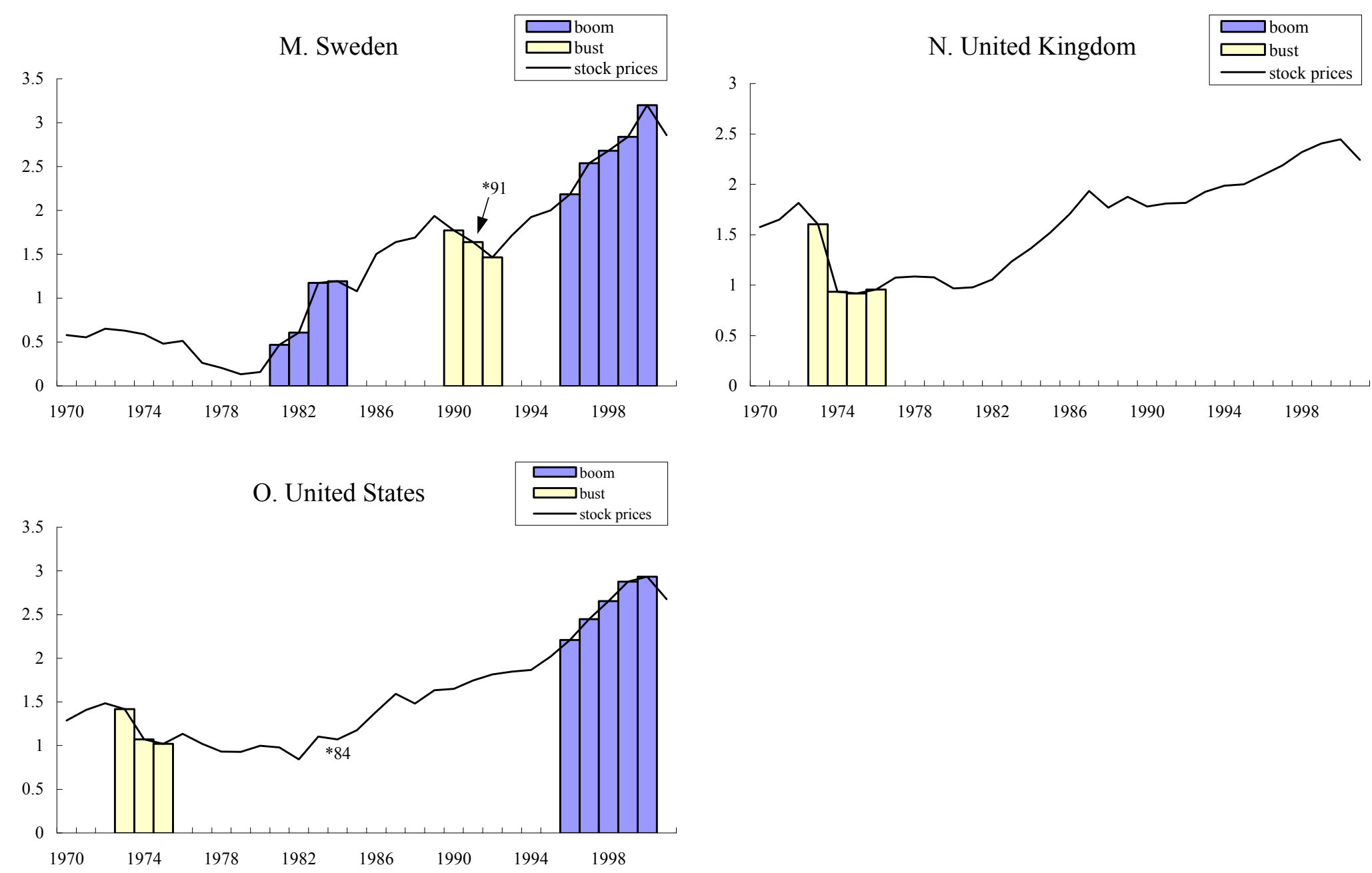

Sources:

International Financial Statistics, World Economic Outlook and country desks, International Monetary Fund.

*Banking crisis. See Eichengreen and Bordo (2002) Appendix A.

** Booms and busts are calculated by a three year moving average. 
Figure 9. U.S. Stock Prices: S\&P 500, 1874-1999**

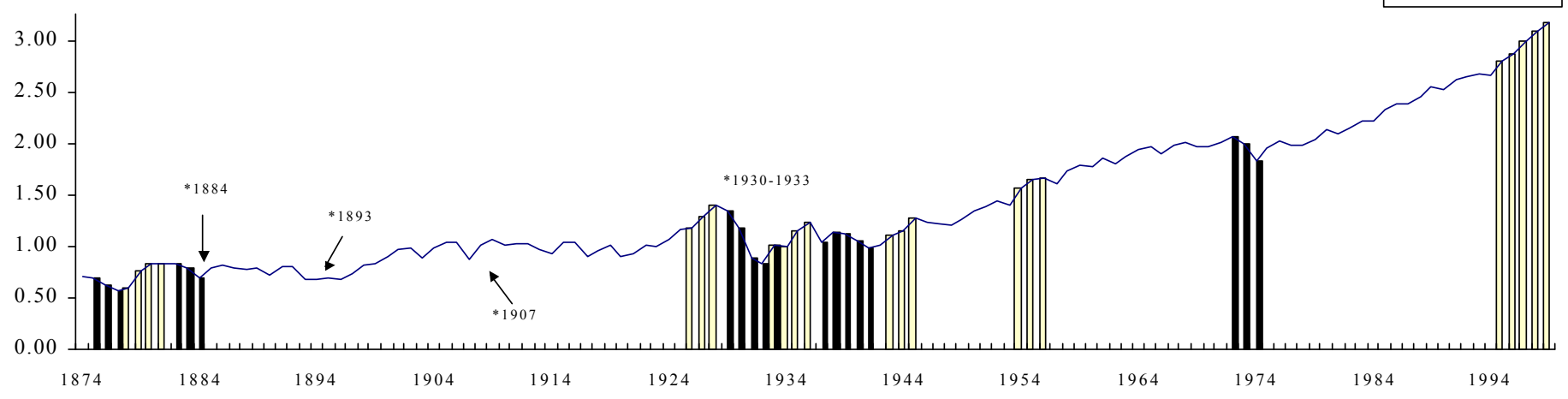

Source:

Historical Statistics of the United States: Millennial Edition (2003)

*Banking crisis. See Eichengreen and Bordo (2002) Appendix A. ** Booms and busts are calculated by a three year moving average.

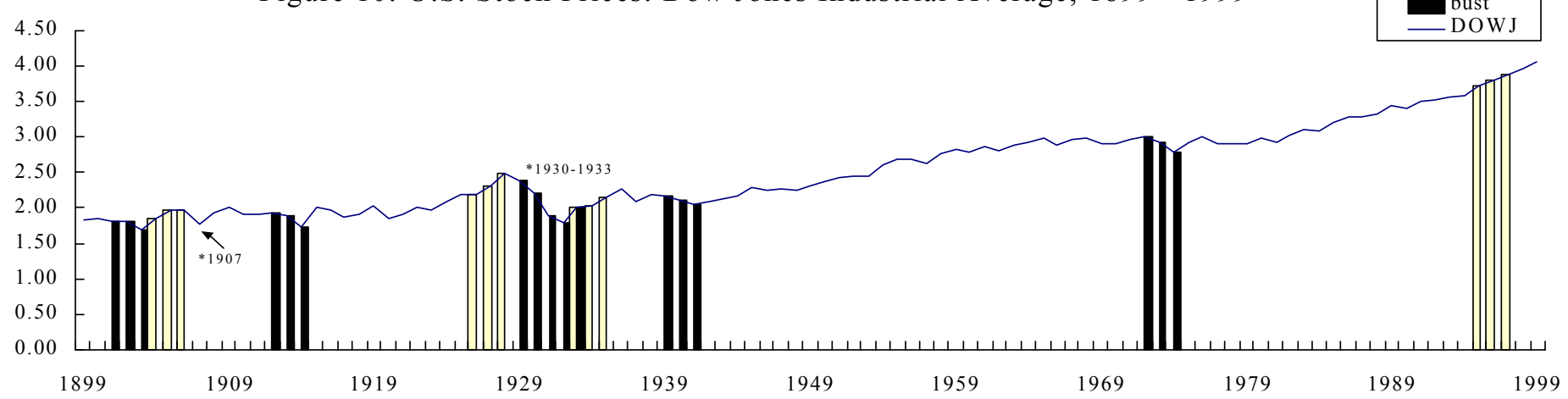

Source:

Historical Statistics of the United States: Millennial Edition (2003)

*Banking crisis. See Eichengreen and Bordo (2002) Appendix A. ** Booms and busts are calculated by a three year moving average. 
Figure 11. Ancillary Variables: Boom-Bust in Property Prices

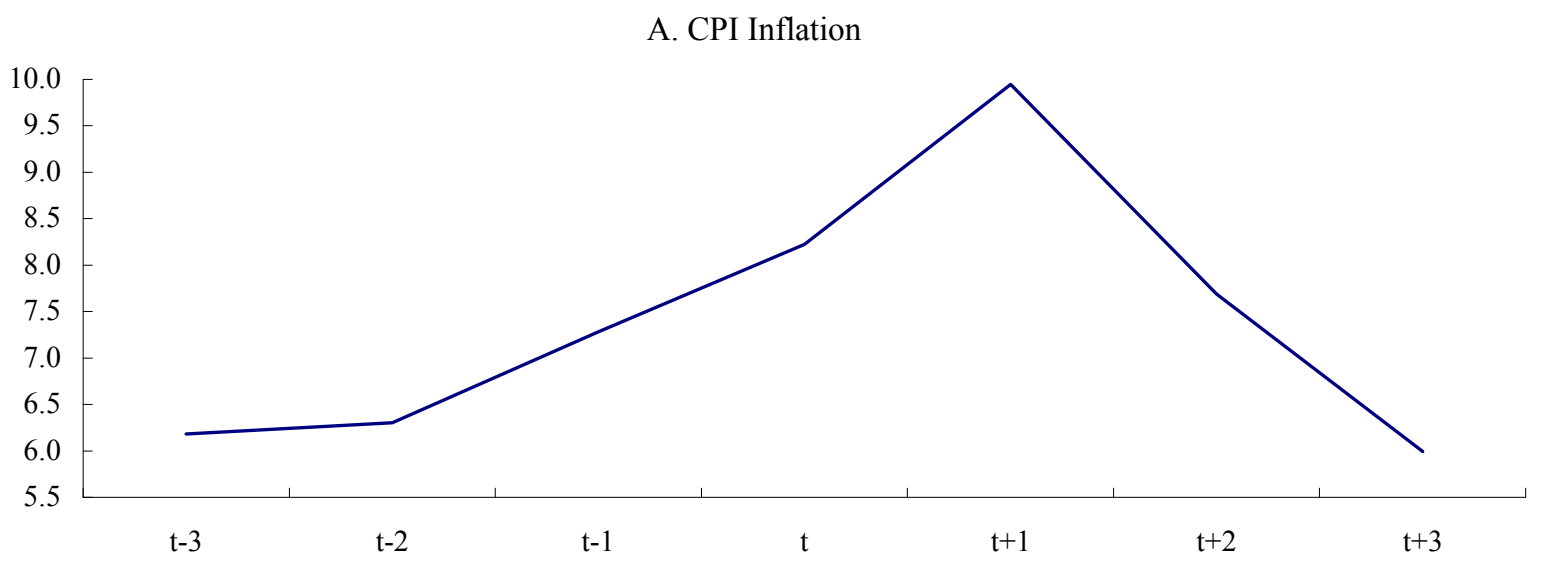

B. Output Gap

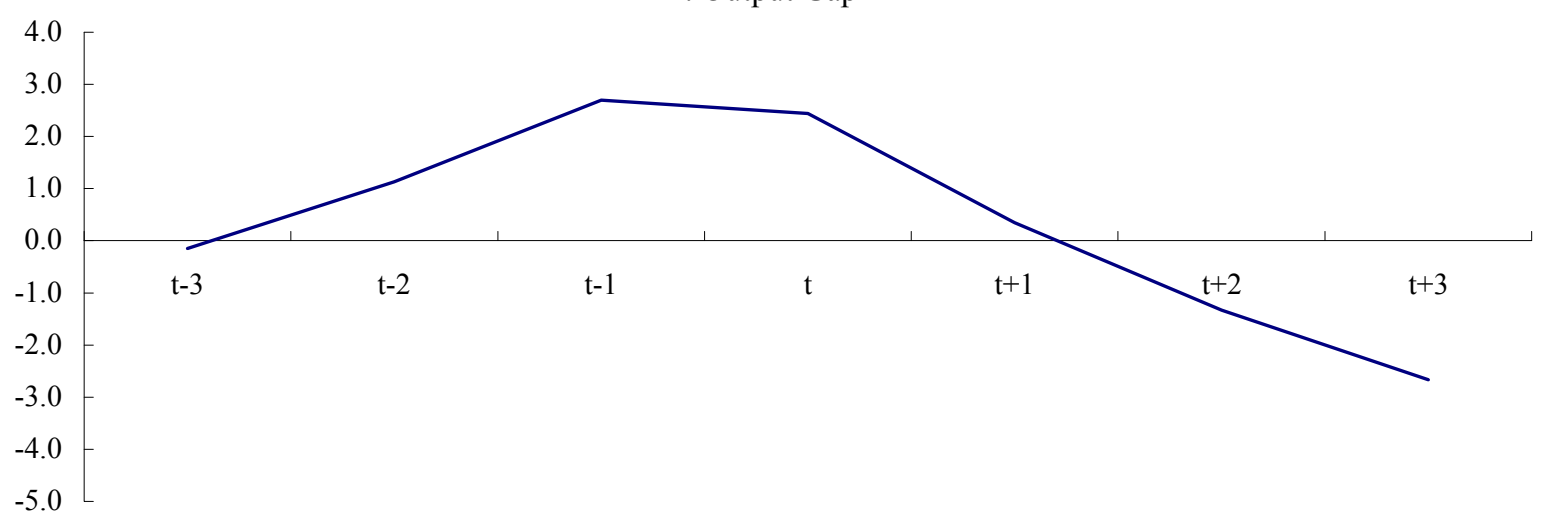

C. Domestic Credit

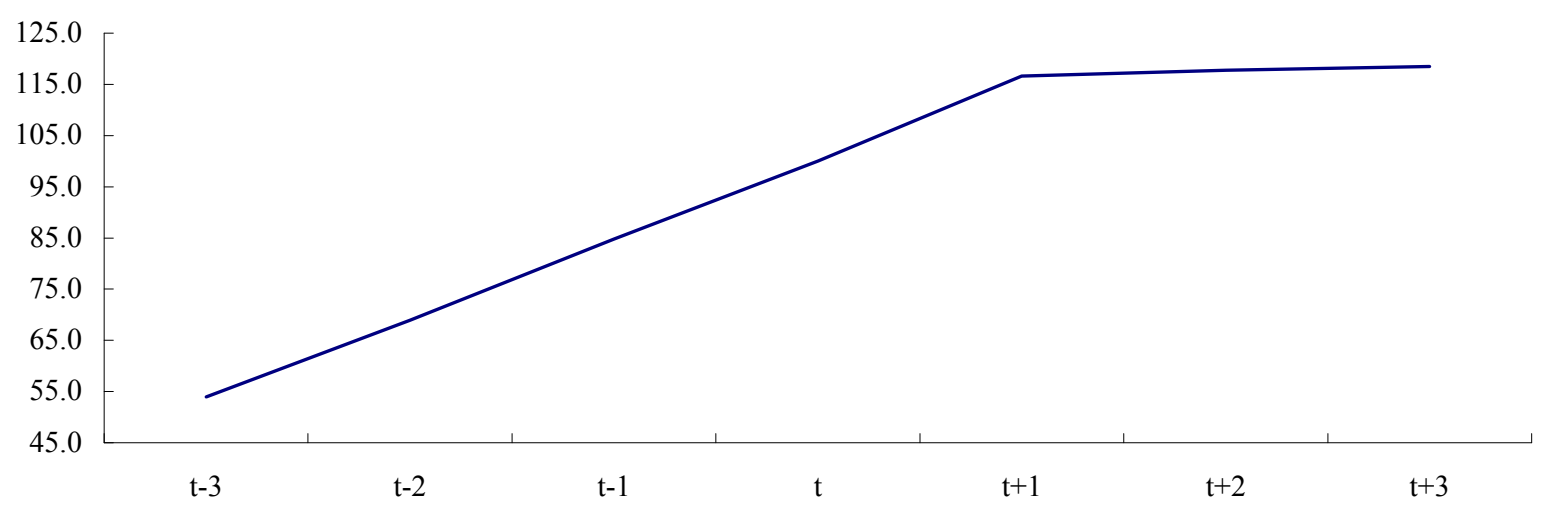

Sources:

International Financial Statistics and World Economic Outlook, International Monetary Fund. 
Figure 12. Ancillary Variables: Boom-Bust in Stock Prices

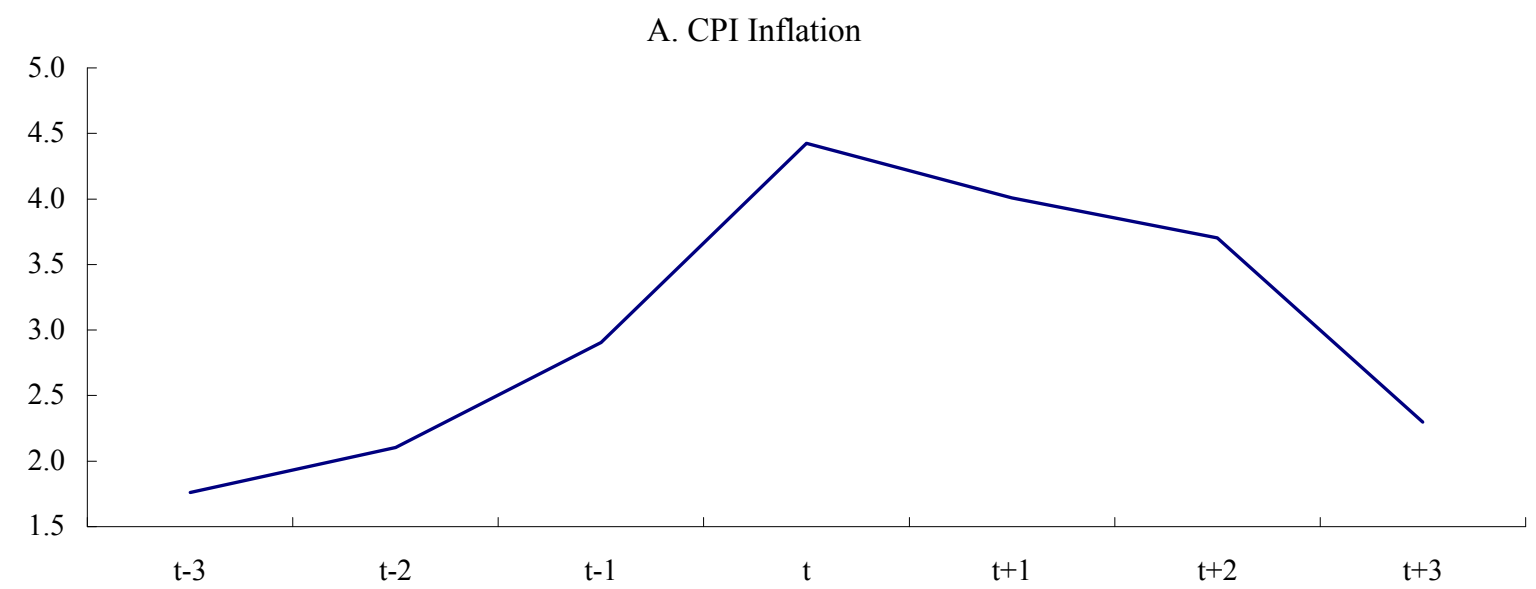

B. Output Gap

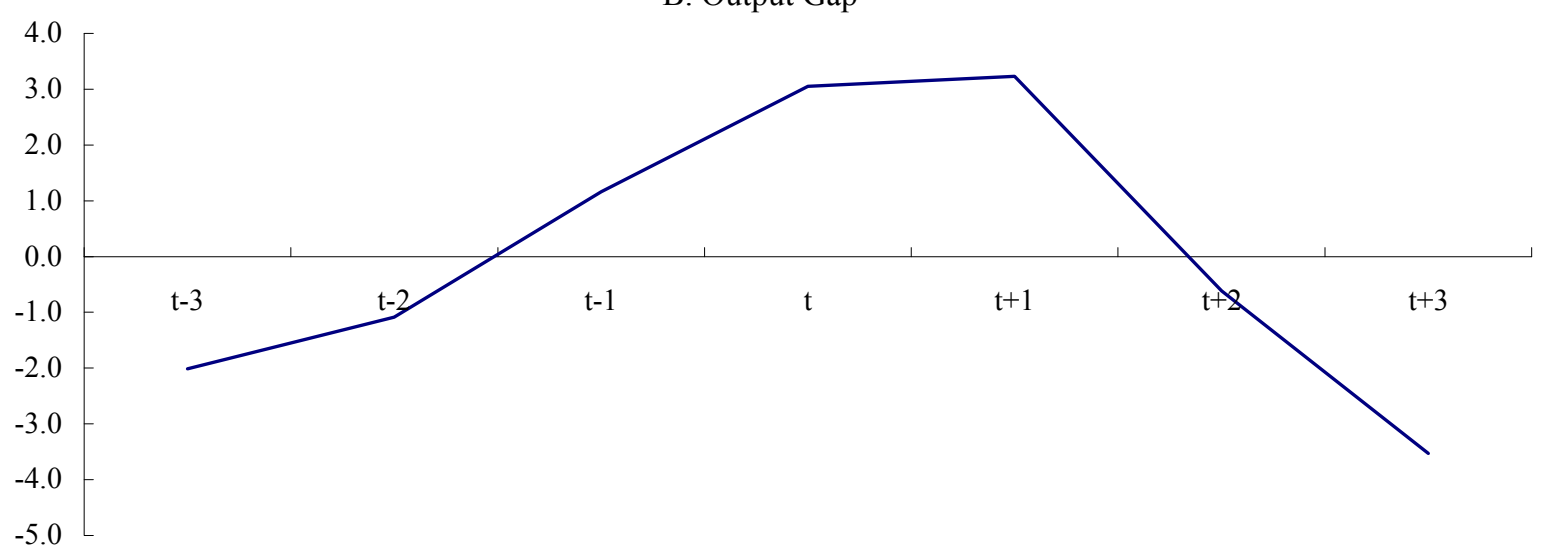

C. Domestic Credit

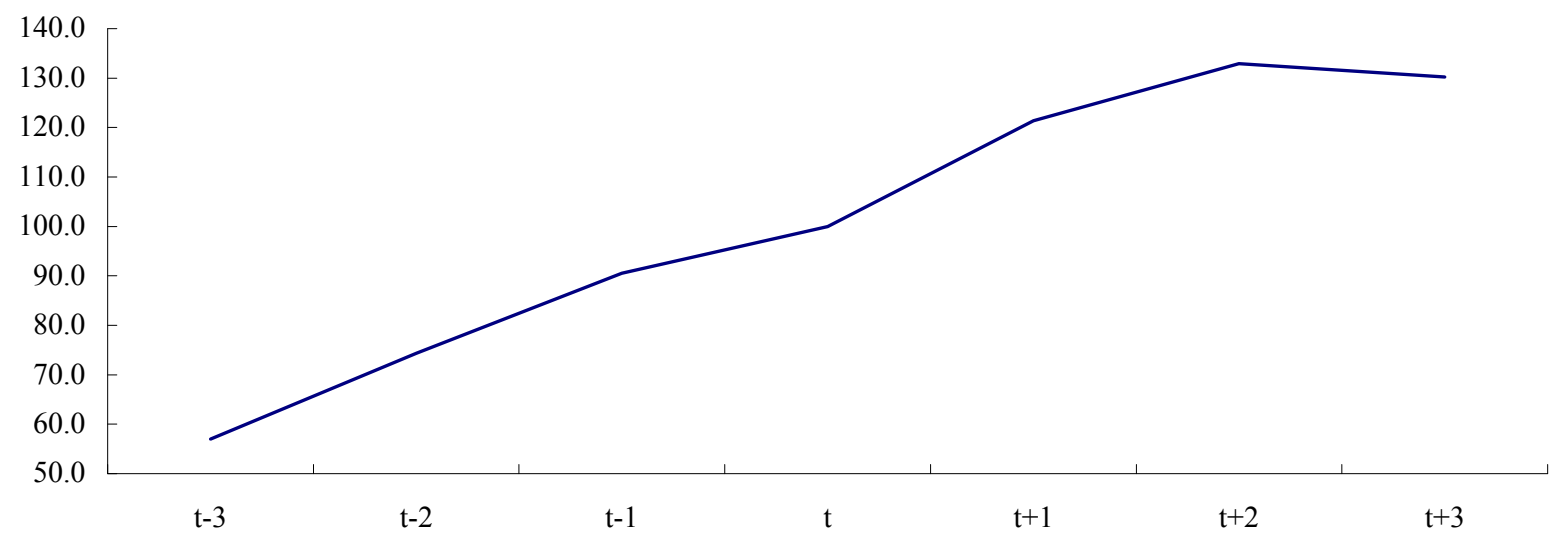

Source:

International Financial Statistics and World Economic Outlook, International Monetary Fund 
Figure 13

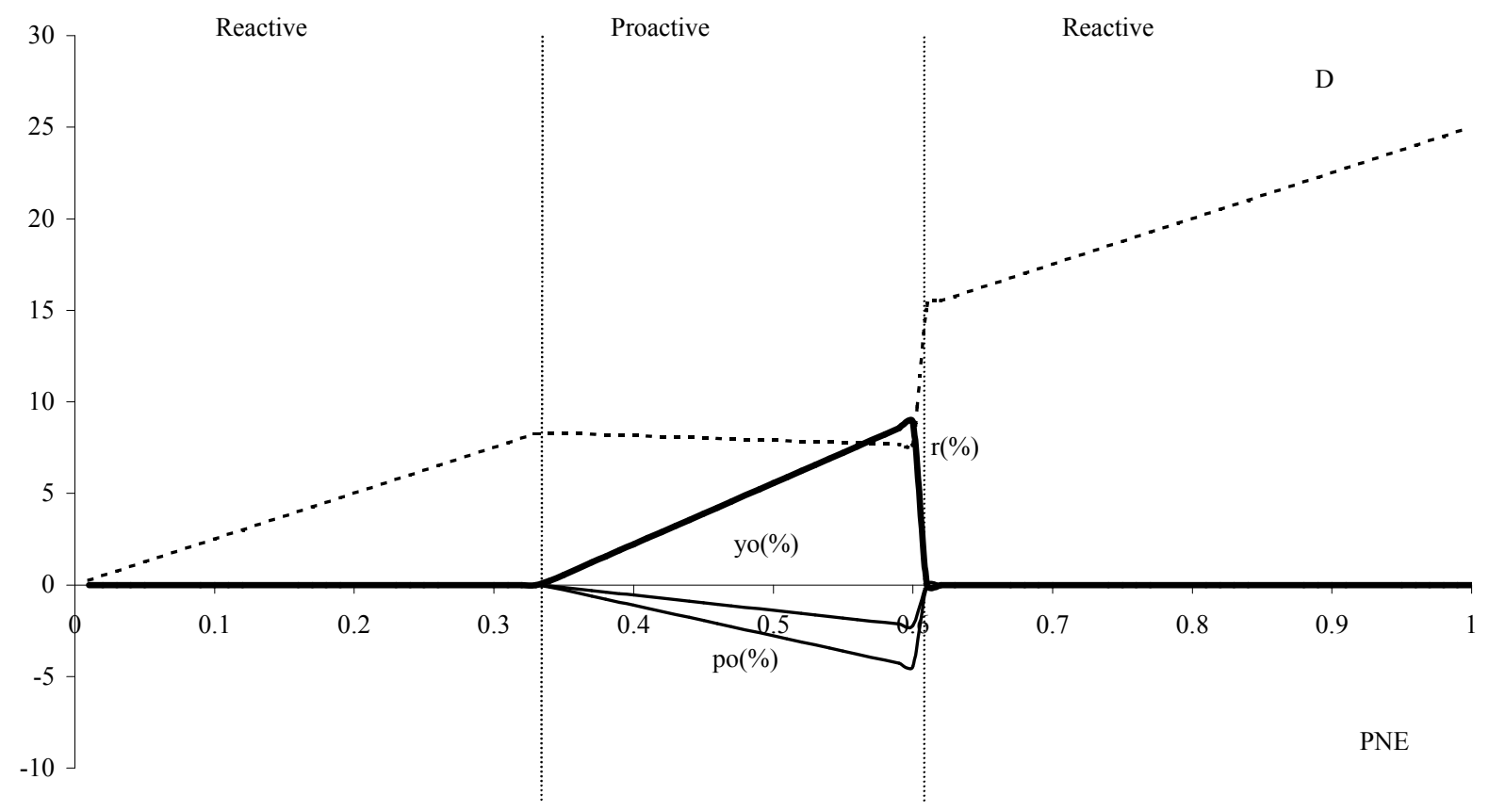

Figure 14

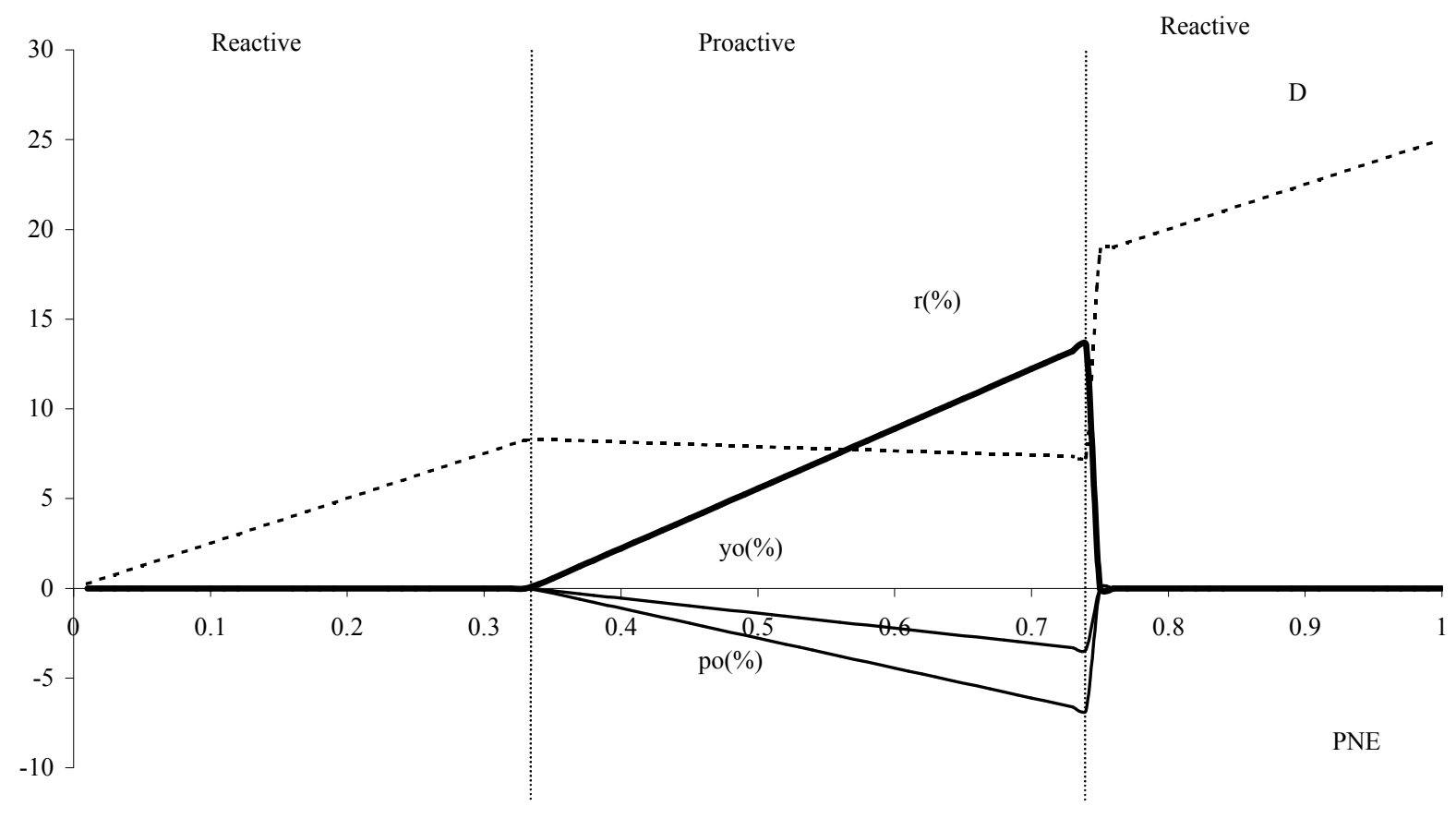

